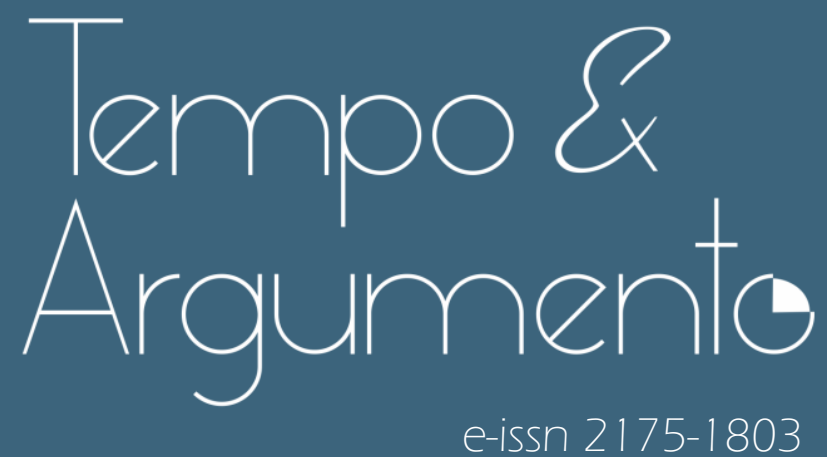

Enquadrando a ditadura: fotojornalismo do Correio da Manhã e os conflitos de 1968

- Jorge Ferreira

Doutor em História Social pela Universidade de São Paulo (USP).

Professor do Programa de Pós-Graduação em História da Universidade Federal

Fluminense (UFF) e da Universidade Federal de Juiz de Fora (UFJF).

Pesquisador IB do Conselho Nacional de Desenvolvimento Científico e

Tecnológico (CNPq).

Rio de Janeiro, RJ - BRASIL

lattes.cnpq.br/4838146606344520

jorge-fer@uol.com.br

(D) orcid.org/0000-0002-3330-8947

Para citar este artigo:

FERREIRA, Jorge. Enquadrando a ditadura: fotojornalismo do Correio da Manhã e os conflitos de 1968. Tempo e Argumento, Florianópolis, v. 12, n. 30, e0201, maio/ago. 2020.

doi http://dx.doi.org/10.5965/2175180312302020e020 1

Recebido: 18/08/2019

Aprovado: 25/03/2020 


\title{
Enquadrando a ditadura: fotojornalismo do Correio da Manhã e os conflitos de 19681
}

\author{
Resumo \\ O artigo analisa o trabalho de fotojornalismo do jornal Correio da Manhã \\ (CM) durante conflitos entre estudantes e policiais militares nas ruas \\ centrais da cidade do Rio de Janeiro, entre março e outubro de 1968. O \\ objetivo é compreender como os fotógrafos recorreram a determinadas \\ composições e enquadramentos para criticar a ditadura militar e defender \\ os estudantes.
}

Palavras-chave: Fotojornalismo. Estudantes - Atividades políticas - Brasil. Correio da Manhã (Jornal) - História.

\section{Framing the dictatorship: Correio da Manhã photojournalism and the 1968 conflicts}

\begin{abstract}
The article analyzes the photojournalism work of the newspaper Correio da Manhã (CM) during conflicts between students and military police in the central streets of the city of Rio de Janeiro, between March and October 1968. The objective is to understand how photographers resorted to certain compositions and frameworks to criticize the military dictatorship and defend the students.
\end{abstract}

Keywords: Photojournalism. Students - Political activities - Brazil. Correio da Manhã (Newspaper) - History. 
O filme $A$ noite dos generais estreou no circuito europeu em janeiro de 1967 com a história de um militar que investiga o assassinato de uma prostituta em Varsóvia durante a Segunda Guerra. Na história, a única testemunha do crime revela que o assassino usava farda de general no momento em que praticara o ato. É provável que o fotógrafo Osmar Gallo, do jornal Correio da Manhã, pouco tenha se importado com o filme ou em fazer propaganda da história. O objetivo era outro. Publicada na primeira página do jornal no dia 30 de março de 1968, o enquadramento da fotografia associava o título da película a soldados da Polícia Militar do Rio de Janeiro (figura 1). No dia anterior, outra imagem fora veiculada nos mesmos moldes na primeira página do jornal: nela, um caminhão repleto de soldados da PM passa diante de cinema cujo letreiro luminoso anuncia o filme $\dot{A}$ queima roupa. A foto do dia 29 foi publicada um dia após o assassinato do estudante Edson Luís pela polícia. Diante dos dois cinemas, o fotografo enquadrou letreiros e soldados, elaborando mensagem crítica à ditadura militar. Osmar Gallo - e não o repórter - fez a pauta da matéria.

Figura 1 - Na fotografia publicada em 30 de março, dois dias após o assassinato do estudante Edson Luís, policiais militares aparecem de prontidão nas ruas centrais da cidade

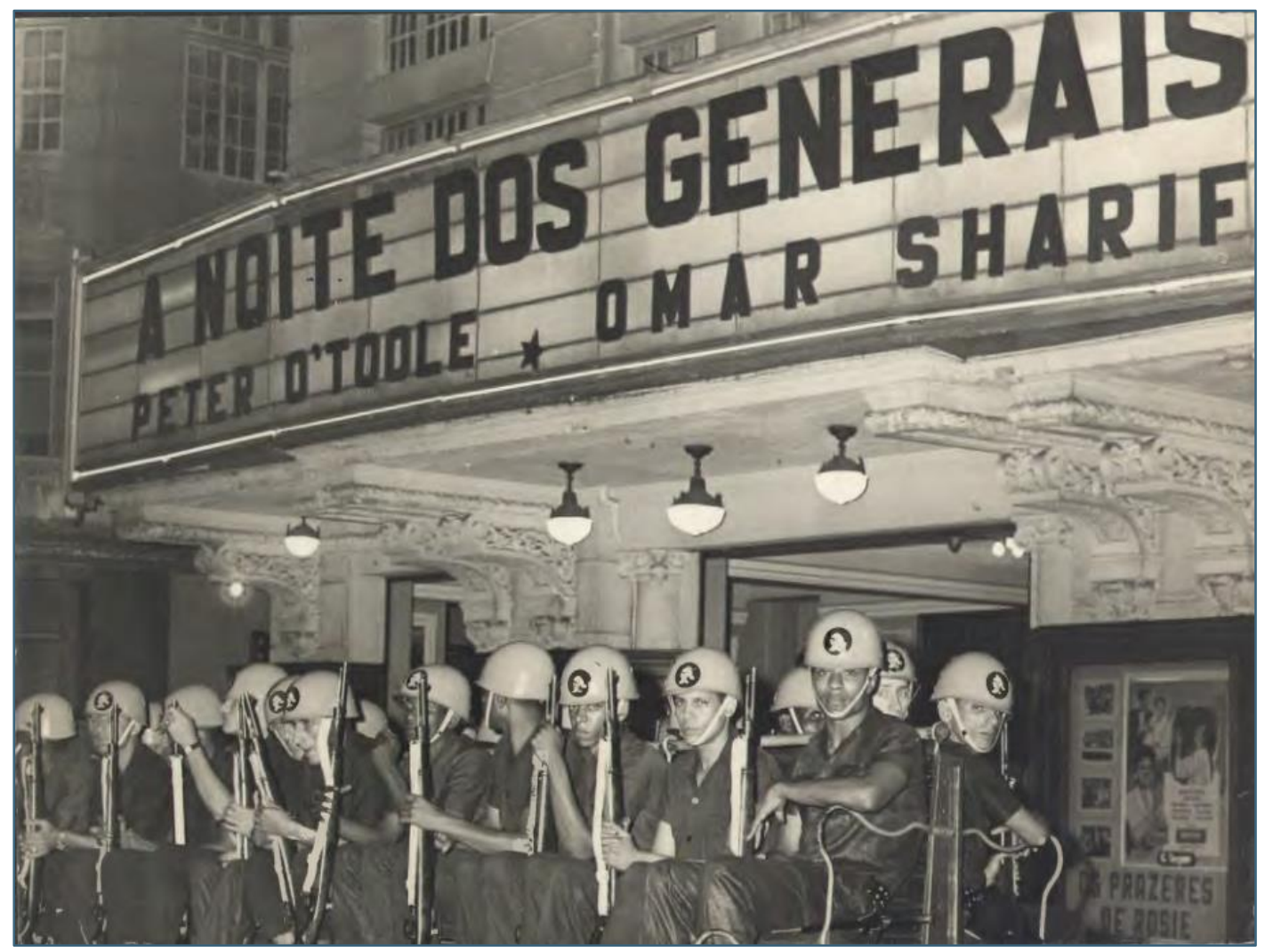

Fonte: Fundo Correio da Manhã - Arquivo Nacional. 
O contexto histórico do artigo tem referência precisa: os conflitos que ocorreram entre estudantes e a Polícia Militar nas ruas centrais do Rio de Janeiro entre março e outubro de 1968. A fonte privilegiada é o conjunto de fotografias do Fundo Correio da Manhã, sob guarda do Arquivo Nacional². O objetivo é analisar a maneira como os fotógrafos do jornal Correio da Manhã (CM) recorreram a composições e enquadramentos fotográficos para criticar a ditadura militar. Trabalho difícil, porque exige que o historiador não tome a fotografia como "algo que ocorreu realmente" no passado, mas sim na direção do que diz Ana Maria Mauad (1996, p. 75) - a fotografia "é uma elaboração do vivido, o resultado de um ato de investimento de sentido, ou ainda uma leitura do real [...]". Compreendo a imagem como o resultado do trabalho do fotógrafo, o qual constrói um sentido para a realidade social em que vive formulando uma mensagem e provocando naquele que a vê uma reação que, igualmente, para ele faz sentido. No artigo, as fotografias nas páginas de Correio da Manhã são compreendidas como documentos dados a "ler".

Todas as fotografias apresentadas têm como referência o que os fotógrafos e os estudiosos definem como olhar fotográfico, diferenciando nessa elaboração o ato de olhar do de fotografar. "É a prática do olhar fotográfico que conduz à transcrição do visível em coisa 'fotografável'”, afirma Luís Humberto. Segundo a definição do autor,

o olhar fotográfico é um hábito visual seletivo, animado por uma percepção sensibilizada por motivações de diversas origens filosóficas, ideológicas, culturais e afetivas - presentes em todos nós, mesmo que nem sempre identificadas de forma nítida. Mas, só estando apoiado em rigoroso e instantâneo domínio dos meios tecnológicos - indispensáveis intermediários entre intenções e resultados - e o competente manejo da linguagem, poderá permitir que seja alcançado um conteúdo de acordo com as expectativas do autor. (HUMBERTO, 2000, p.46).

O conceito de olhar fotográfico acompanhará as páginas seguintes. Se o seu resultado são imagens que produzem sentido, vale ressaltar que em muitas fotografias encontramos textos escritos nas ruas. Trata-se de ato proposital dos fotógrafos. Eles recorriam a frases ou pichações nas ruas em suas composições

\footnotetext{
${ }^{2}$ As fotografias foram pesquisadas em fundo arquivístico do Arquivo Nacional e não no próprio jornal. Por isso nem sempre é possível citar dia e mês em que a fotografia foi publicada. Poucas apresentam data escrita no verso.
} 
fotográficas para criticar a violência policial e a ditadura militar. Nesse sentido, tais imagens continuam sendo compreendidas como textos passíveis de leitura, havendo nelas também outros registros - os escritos. É essa modalidade de fotografia a privilegiada para a análise.

Finalmente, vale ressaltar que a reflexão e a pesquisa acadêmica voltadas para as relações entre história, fotografia e cultura visual têm produzido resultados originais e plurais. A começar por Boris Kossoy, cujo livro publicado em 1988 abriu perspectivas para vasto campo de estudo das relações entre fotografia e história.

Desde os anos 1990, a produção acadêmica sobre cultura visual ganhou grande fôlego nas áreas de História, Comunicação Social e Artes devido a pesquisas realizadas em programas de pós-graduação. A produção acadêmica atual é considerável e não há lugar aqui explorar o avanço nessa área de estudo, até mesmo porque existem balanços bibliográficos e historiográficos sobre o tema ${ }^{3}$. Vale destacar que uma das direções tomadas pelos estudos de cultura visual foi o fotojornalismo. Para citar apenas dois historiadores que vêm se dedicando ao tema, cito Ana Maria Mauad e Charles Monteiro. Diversas dissertações de mestrado e teses de doutorado têm como tema o fotojornalismo.

\section{Correio da Manhã: do conservadorismo liberal à defesa da democracia}

Fundado em 1901 por Edmundo Bittencourt e tendo direção de seu filho, Paulo Bittencourt, em 1929 o Correio da Manhã (CM) era um dos mais importantes jornais do país. Na experiência liberal-democrática que se abriu em 1945, o periódico adotou postura anticomunista e antigetulista, alinhando-se com o programa liberal da União Democrática Nacional (UDN). Desde a democratização de 1945, o CM defendeu a democracia liberal, com ênfase no liberalismo. O antigetulismo levou o jornal a apoiar não só o Manifesto dos Coronéis com críticas de militares ao ministro do Trabalho, João Goulart, bem como o inquérito

\footnotetext{
${ }^{3}$ Ver: MONTEIRO, Charles. A pesquisa em História e Fotografia no Brasil: notas bibliográficas. Anos 90, Porto Alegre, v. 15, n. 28, p. 196 - 185, dez. 2008
} 
policial-militar instaurado pela Força Aérea Brasileira para investigar o atentado contra Carlos Lacerda, em agosto de 1954. A mudança na linha editorial do jornal ocorreria nas eleições presidenciais de outubro de 1955. Na época, Paulo Bittencourt mostrou-se crítico a todos os candidatos, mas as páginas do jornal demonstravam apoio à candidatura de Juscelino Kubitschek (LEAL, c2009). Quando grupos civis e militares tentaram impedir a posse de Juscelino, CM defendeu a continuidade do processo democrático.

A partir daí, o jornal tomou posições democráticas e até progressistas: publicou reportagens de Antônio Callado sobre as Ligas Camponesas em 1959; apoiou a candidatura de Henrique Teixeira Lott em 1960; criticou Jânio Quadro pela renúncia; defendeu a posse de João Goulart em agosto de 1961; respaldou a posição do governo brasileiro de não intervenção em Cuba, o que the custou verbas publicitárias; e, em parceria com o jornal Folha de S. Paulo, realizou o Congresso Brasileiro para a Definição das Reformas de Base, em janeiro de 1963.

Também em 1963, com o falecimento de Paulo Bittencourt, a viúva do jornalista, Srạ. Niomar Muniz Sodré Bittencourt, assumiu a direção do jornal. O Correio da Manhã foi favorável ao plebiscito de 1963, ao retorno do regime presidencialista e ao Plano Trienal. Ao lado de outros atores políticos da época, apoiou o governo Goulart, desde que controlasse a inflação e estivesse afastado das esquerdas (MOTTA, 2002, p. 252). Como outros jornais, passou para a oposição em fins de 1963, após a revolta dos sargentos em Brasília e a crise que resultou no pedido de estado de sítio pelo presidente. Mesmo assim, o jornal não se referia a golpes de Estado ou ao afastamento de Goulart do poder. A linha editorial mudaria após o comício de 13 de março de 1964. A aliança do presidente com as esquerdas e o movimento sindical era intolerável não apenas para as direitas mas também para os liberais.

A ruptura veio com a anistia que Goulart concedeu aos marinheiros rebelados, interpretada como inaceitável pela redação do jornal. Sem que tenha participado da conspiração golpista, o Correio da Manhã publicou dois editoriais de enorme repercussão: "Basta", em 31 de março, e "Fora”, em 1ำ de abril. Os redatores do $\mathrm{CM}$, da mesma maneira que muitos outros atores políticos, tinham como objetivo tão somente retirar João Goulart da presidência da República - e 
não instaurar o autoritarismo no país. Logo os redatores perceberam que suas expectativas foram frustradas: havia uma ditadura. No dia 3 de abril, denunciando as perseguições e as prisões arbitrárias a mando do governador Carlos Lacerda, a manchete do jornal dizia: "Terrorismo não".

Segundo estudos de Gil Vicente Oliveira, a diretora-presidente do jornal, Niomar Muniz Sodré Bittencourt, foi convencida por Otto Maria Capeaux e Edmundo Muniz a orientar o periódico para linha editorial de oposição à ditadura4. Ela não apenas concordou com os colaboradores como também investiu no fotojornalismo. Assim, já em fins de abril de 1964, Erno Schneider foi contratado e assumiu o cargo especialmente criado para ele, editor de fotografia. Até então, Erno era fotógrafo do Jornal do Brasil, tendo ganho o Prêmio Esso com a conhecida fotografia de Jânio Quadros com os pés apontados para lados diferentes. De Niomar, Erno recebeu autonomia para contratar novos fotógrafos e modernizar o equipamento do jornal (OLIVEIRA, 1998, p. 118). Luiz Vilhena assumiu como laboratorista fotógrafo, profissional que faltava ao jornal. Aos fotógrafos que já trabalhavam no jornal, como Luis Bueno Filho e Manoel Gomes da Costa, Erno Schneider agregou Alberto França, Morales, Rubens Seixas e Milton Santos, constituindo equipe de profissionais gabaritados. Também adquiriu equipamentos modernos, como máquinas fotográficas dotadas de teleobjetivas.

Erno Schneider ampliou o espaço de atuação dos fotógrafos. Em sua pesquisa, Gil Oliveira afirma que os fotógrafos, até então, somente acompanhavam os repórteres, ilustrando com imagens as matérias que seriam redigidas mais tarde. Erno estimulou os fotógrafos a proporem e realizarem "suas próprias matérias, através de ensaios fotográficos". Algo arrojado, sem dúvida, porque na época apenas os fotógrafos das grandes revistas, como O Cruzeiro, tinham reconhecimento profissional (OLIVEIRA, 1998, p. 119). Seguindo as

\footnotetext{
${ }^{4}$ Rodrigo Patto Sá Motta critica as interpretações simplistas que reduzem os jornais a meros instrumentos da dominação burguesa ou de estratégias estatais. Sem descartar da análise que os periódicos são empresas capitalistas e sofrem influências do Estado, a imprensa, afirma Motta, "também sofre influência do público, da sua clientela: por isso, estratégias de mercado, em certas situações, marcam as escolhas políticas dos editores. Por outro lado, é fundamental considerar a opinião política dos proprietários da empresa ou de seus editores que, às vezes, adotam estratégias arriscadas motivadas por suas convicções” (MOTTA, 2013, p. 65). Muito possivelmente essa é a explicação para a linha editorial adotada no Correio da Manhã por Niomar Bittencourt, Otto Maria Capeaux e Edmundo Muniz.
} 
indicações de Henri Cartier-Bresson, a orientação era privilegiar a fotografia espontânea, sem preparação anterior ou posada. Estimulava-se a criatividade para que o fotógrafo não atuasse como simples ilustrador da notícia com imagem informativas, mas que também opinasse com suas lentes (OLIVEIRA, 1998, p. 120). Nas fotos, davam-se créditos ao autor, algo inédito até então. Schneider também negociou melhores salários para os fotógrafos.

\section{Enquadrando a Polícia Militar}

Os fotógrafos procuravam textos nas ruas que, de alguma maneira, denunciassem a violência e o autoritarismo da ditadura militar. Um dos recursos mais utilizados por eles foi enquadrar soldados da PM embaixo de letreiros de cinemas - é o que chamamos de olhar fotográfico. O título do filme no letreiro do cinema dava o sentido e o tom da crítica. Sem o letreiro, a fotografia tomaria outro significado, apresentando apenas os soldados. O letreiro sem os soldados, por sua vez, ganharia sentido de divulgação - algo pouco desejado, afinal, o fotógrafo não estava a serviço do caderno cultural do jornal.

A noite dos generais é um exemplo do resultado do olhar fotográfico. Em outra imagem estampada no jornal, observa-se que o letreiro do filme Uma nova cara no inferno toma praticamente todo o plano focal (figura 2). Mas não há apenas o título do filme, aparecem os nomes dos atores principais - George Peppard e Raymond Burr - e os horários de exibição no cinema Odeon. Em linguagem fotográfica, o autor subverte a composição da imagem. Composição é a maneira como os elementos da fotografia são dispostos, a começar pelo assunto principal, no primeiro plano, conjugado a elementos secundários, tudo sem descuidar da harmonia e da estética visual. O fotógrafo, ao sair nas ruas, teria que mirar como elemento central os soldados. Nesse sentido, o letreiro deveria ser o seu elemento secundário. No entanto, toma na foto praticamente toda a cena. Os soldados deveriam surgir como personagens centrais, mas aparecem na imagem de maneira secundária - e, não casualmente, somente suas cabeças. Trata-se de uma composição subvertida, mas não de maneira arbitrária. O fotógrafo associa o título do filme aos rostos dos policiais militares. Se há Uma nova cara no inferno, é a dos policiais. Ou melhor, a nova cara é a 
ditadura. Há, contudo, que se reavaliar a composição da fotografia, compreendendo que o elemento central nela é o conjunto: soldados e letreiro. O conjunto elabora a mensagem crítica. Se isolados, soldados e letreiro não diriam muita coisa; juntos, formam o elemento central da fotografia: a crítica à ditadura.

Figura 2 - Fotografados em frente ao cinema, policiais aguardam protestos estudantis no dia 10 de abril

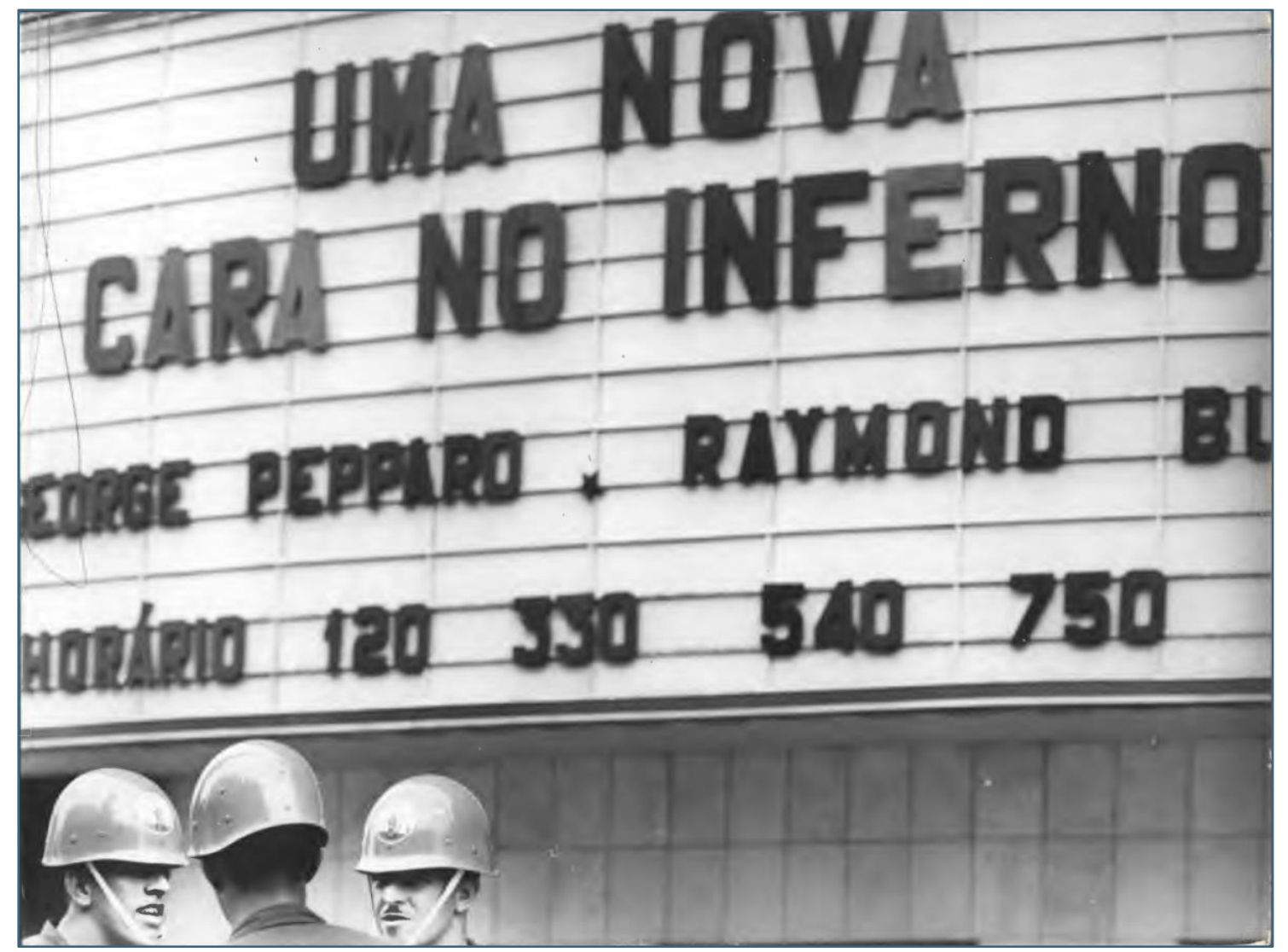

Fonte: Fundo Correio da Manhã - Arquivo Nacional.

Schneider fez algo novo na redação do Correio da Manhã: propôs aos fotógrafos que sugerissem as pautas que orientavam seus ensaios. Um dos temas preferidos deles foi a violência policial. Ainda recorrendo ao conjunto letreiro-soldados, os filmes estilo westerns eram bons motivos, caso do Festival Bang Bang (figura 3) e do filme A vingança de Ringo (figura 4). Vale ressaltar que os filmes de faroeste ocorriam sempre nas épocas e nos lugares em que vigorava a lei do mais forte - de preferência armado. 
Figura 3 - Na edição de dia 7 de agosto há fotografia de policiais militares agrupados em frente a um cinema.

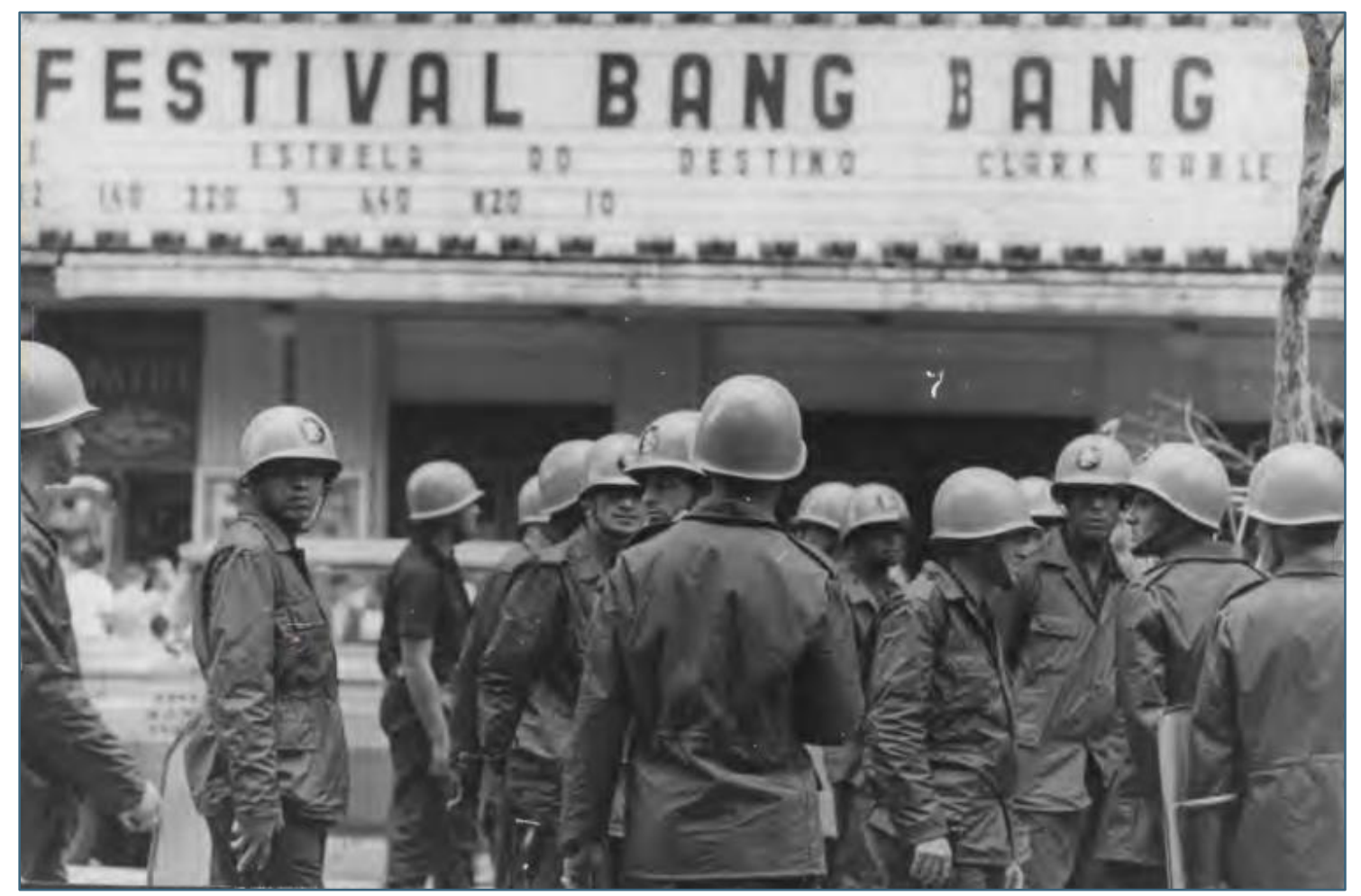

Fonte: Fundo Correio da Manhã - Arquivo Nacional.

Figura 4 - No dia 2o de abril de 1968, Correio da Manhã publicou fotografia de policiais militares que, no dia anterior, estavam à espera de protestos dos estudantes pela passagem dos quatro anos do golpe de Estado

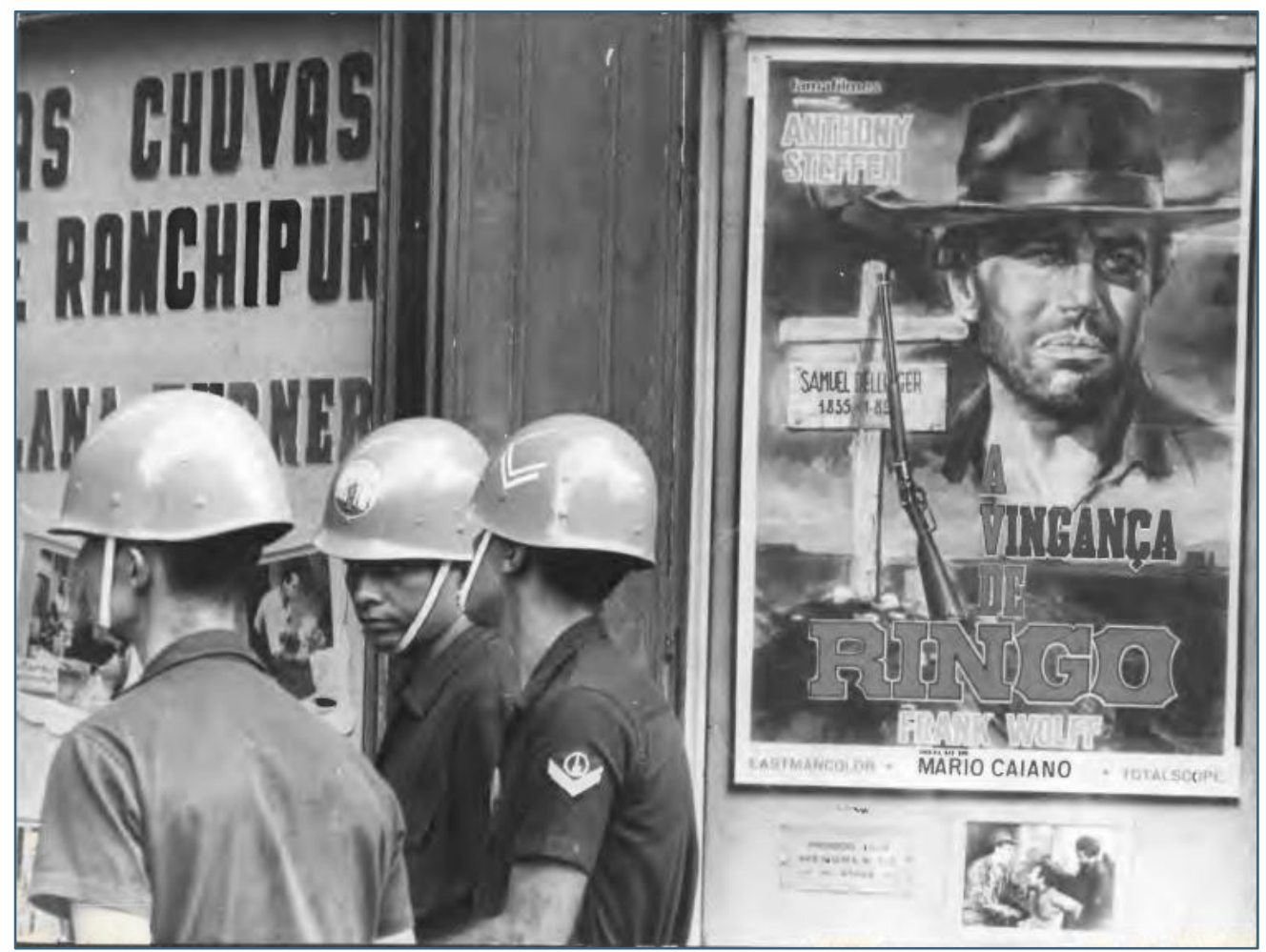

Fonte: Fundo Correio da Manhã - Arquivo Nacional. 
No caso da fotografia do filme do Ringo, não é casual e nada há de inocente no fato de o cartaz ocupar igual espaço dos três soldados. O mesmo espaço para policiais e o cartaz de Ringo. O fotógrafo está produzindo um sentido para a imagem que registra. É por isso que, anteriormente, ressaltei que, desde muito tempo, foi criticada e superada a "ideia de que o que está impresso na fotografia é a realidade pura e simples” (MAUAD, 1996, p. 75). Reforço a afirmação recorrendo a Boris Kossoy:

qualquer que seja o assunto registrado na fotografia, esta também documentará a visão de mundo do fotógrafo. A fotografia é, pois, um duplo testemunho: por aquilo que ela nos mostra da cena passada, irreversível, ali congelada, fragmentariamente, e por aquilo que nos informa acerca de seu autor. [...] Toda fotografia representa o testemunho de uma criação. Por outro lado, ela representará sempre a criação de um testemunho. (KOSSOY, 2014, p. 54).

\section{Compondo com os estudantes}

Ao longo de 1968, entre março e outubro, ocorreram muitos protestos nas ruas centrais do Rio de Janeiro. O estopim foi o assassinato do jovem Edson Luís de Lima e Souto, no dia 28 de março, morto pela polícia. Junho foi o mês mais violento no conflito entre estudantes, armados com paus e pedras, e a Polícia Militar, com seus cavalos, cassetetes, armas de fogo, baionetas e bombas de gás lacrimogêneo.

Segundo Pitts Bryan, até o assassinato do jovem Edson, as manifestações estudantis demandavam questões voltadas para a educação, como mais vagas nas universidades e a democratização da gestão universitária. Com exceção dos estudantes que militavam em organizações de esquerda, a maioria deles não tinha no horizonte a derrubada da ditadura. "Mas com essa morte violenta de um observador inocente que, por todos os relatos, não tinha nenhum envolvimento com a política estudantil, os protestos de estudantes explodiram por todo o país", conclui o autor (PITTS, 2014, p. 43).

A morte de Edson Luís foi um divisor de águas. Cerca de 50 mil pessoas acompanharam o cortejo fúnebre. No dia 1o de abril, quatro anos após o golpe de Estado, os estudantes realizaram manifestações nas ruas centrais do Rio de 
Janeiro. No dia 4, na missa de sétimo dia, a cavalaria da Polícia Militar investiu contra todos que estavam na porta e nas imediações da igreja da Candelária. No dia 20 de junho, estudantes reunidos em assembleia na Reitoria da UFRJ foram cercados por policiais. Eles tentaram furar o cerco com paus e pedras, mas cerca de 300 foram presos e levados para o campo de futebol do Botafogo, onde foram espancados e sofreram humilhações. No dia seguinte ocorreu manifestação conhecida como "sexta-feira sangrenta". Segundo Daniel Aarão Reis e Pedro de Moraes, os estudantes protestaram contra as violências do dia anterior e muitos morreram.

Dessa vez, no entanto, a cidade reagiu como pode, usando paus, pedras, objetos contundentes jogados do alto das janelas, fios de arame para derrubar os cavalos. A batalha durou mais de sete horas e levou à prisão mais de mil pessoas. Mas a polícia também foi obrigada a contar suas baixas: um morto, 35 feridos, mais de 10 camburões incendiados. (REIS; MORAES, 2008, p. 24).

João Roberto Martins Filho ressalta que a sexta feira sangrenta foi um dos "maiores conflitos urbanos da história do país" (MARTINS FILHO, 1987, p. 141), com a morte de 28 pessoas, resultando, dias mais tarde, na Passeata dos Cem Mil, "quando o governo federal ordenou um recuo tático, retirando das ruas o aparato militar e permitindo a manifestação" (MARTINS FILHO, 1987, p. 141).

Testemunhas de época, como Zuenir Ventura, relatam que a tática usada pelos estudantes era simples, mas eficaz: os chamados pelotões suicidas atraíam grupos de soldados para determinado lugar, enquanto o conjunto dos estudantes avançava em passeata para outro. Líderes e coordenadores de grupos eram protegidos por estudantes com porte físico avantajado, próprio para enfrentar os policiais (VENTURA, 1988, p. 109). O fotógrafo Evandro Teixeira, na época trabalhando no Jornal do Brasil, lembra que os estudantes usavam bolinhas de gude para derrubar os cavalos. Mas a cavalaria saía dos quartéis disposta a tudo. Estudantes morreram vítimas de baionetas ou de armas de fogo. Ainda segundo seu depoimento, o Jornal do Brasil apoiava a luta dos estudantes (TEIXEIRA, 2012, p. 238).

Com avanços e recuos, o movimento estudantil, embora dividido em várias correntes, enfrentou a polícia pelo menos até outubro de 1968 em constantes batalhas no centro da cidade. 
Os letreiros nos cinemas eram recursos utilizados para criticar a ditadura militar e seu braço armado, a Polícia Militar. Clamor de Justiça, título do filme em cartaz, no sentido dado pelo fotógrafo, indica o motivo para os estudantes estarem nas ruas: justiça (figura 5).

Figura 5 - No dia 7 de agosto, policiais militares surgem na página do Correio da Manhã se posicionando para enfrentar estudantes

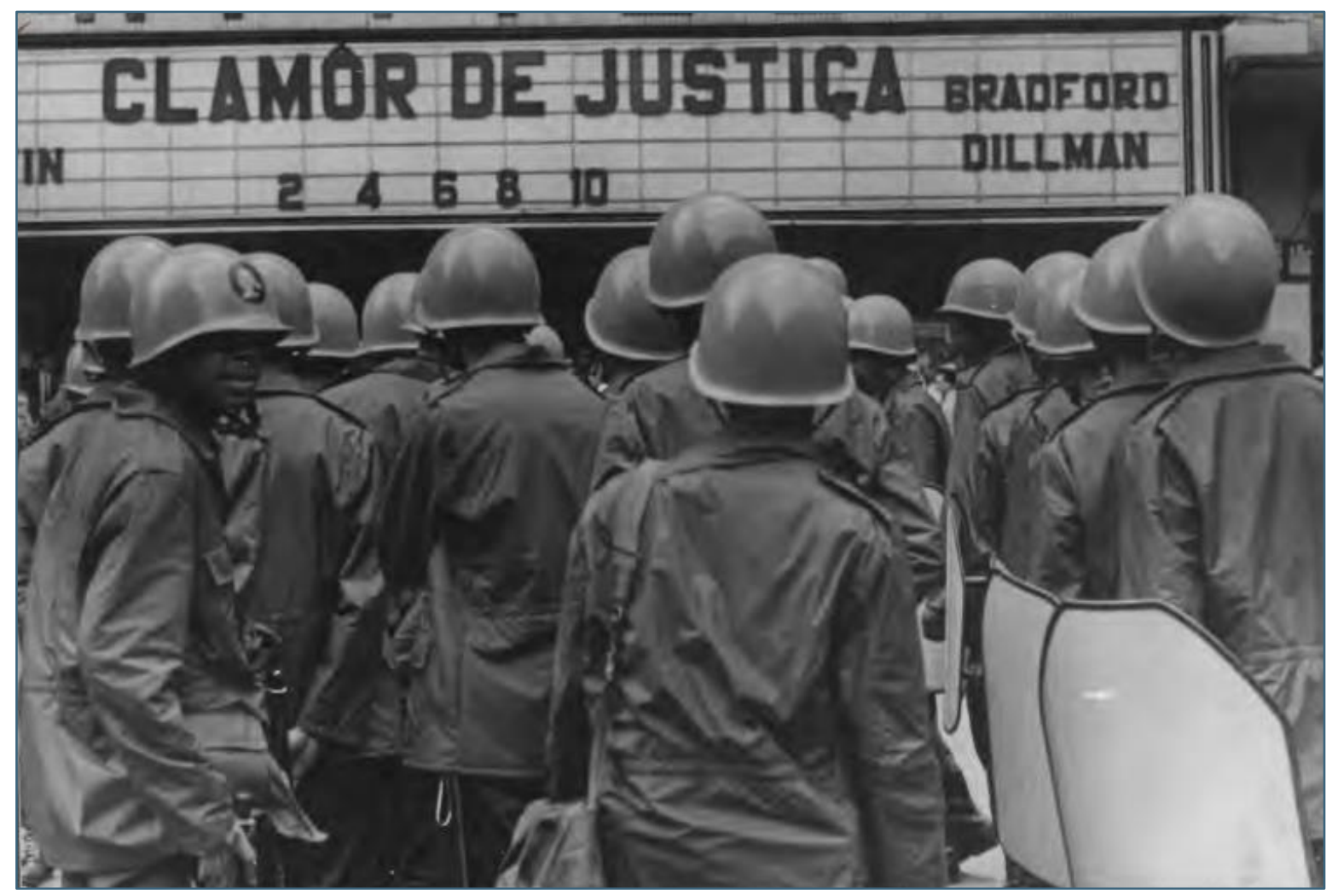

Fonte: Fundo Correio da Manhã - Arquivo Nacional.

Os fotógrafos tomavam posição em relação ao conflito entre estudantes e Polícia Militar. Eles estavam do lado dos estudantes. Vladimir Palmeira, liderança destacada na época, avaliou, muitos anos depois, em fins dos anos 1980, o apoio da imprensa. Segundo suas impressões: "a grande imprensa reproduzia em escala ampliada as ações estudantis. Então, mesmo quando criticavam, não deixavam de divulgar" (PALMEIRA, apud REIS; MORAES, 2008, p. 110). O Correio da Manhã se posicionou frontalmente contra a ditadura militar e manteve apoio ostensivo à luta estudantil.

Os fotógrafos recorriam a letreiros de cinema para compor texto dentro da fotografia, resultando no que se considera ser o texto dentro do texto. Se os 
estudantes clamavam por justiça, eles também surgiam como Os poderosos (figura 6). Na imagem, um estudante discursa sobre um automóvel, parando o trânsito. Os fotógrafos recorriam a letreiros de cinema para criticar a polícia, mas faziam o mesmo para elogiar e defender os estudantes.

Figura 6 - Na primeira página da edição de 4 de agosto, estudante faz comíciorelâmpago sobre capota de automóvel

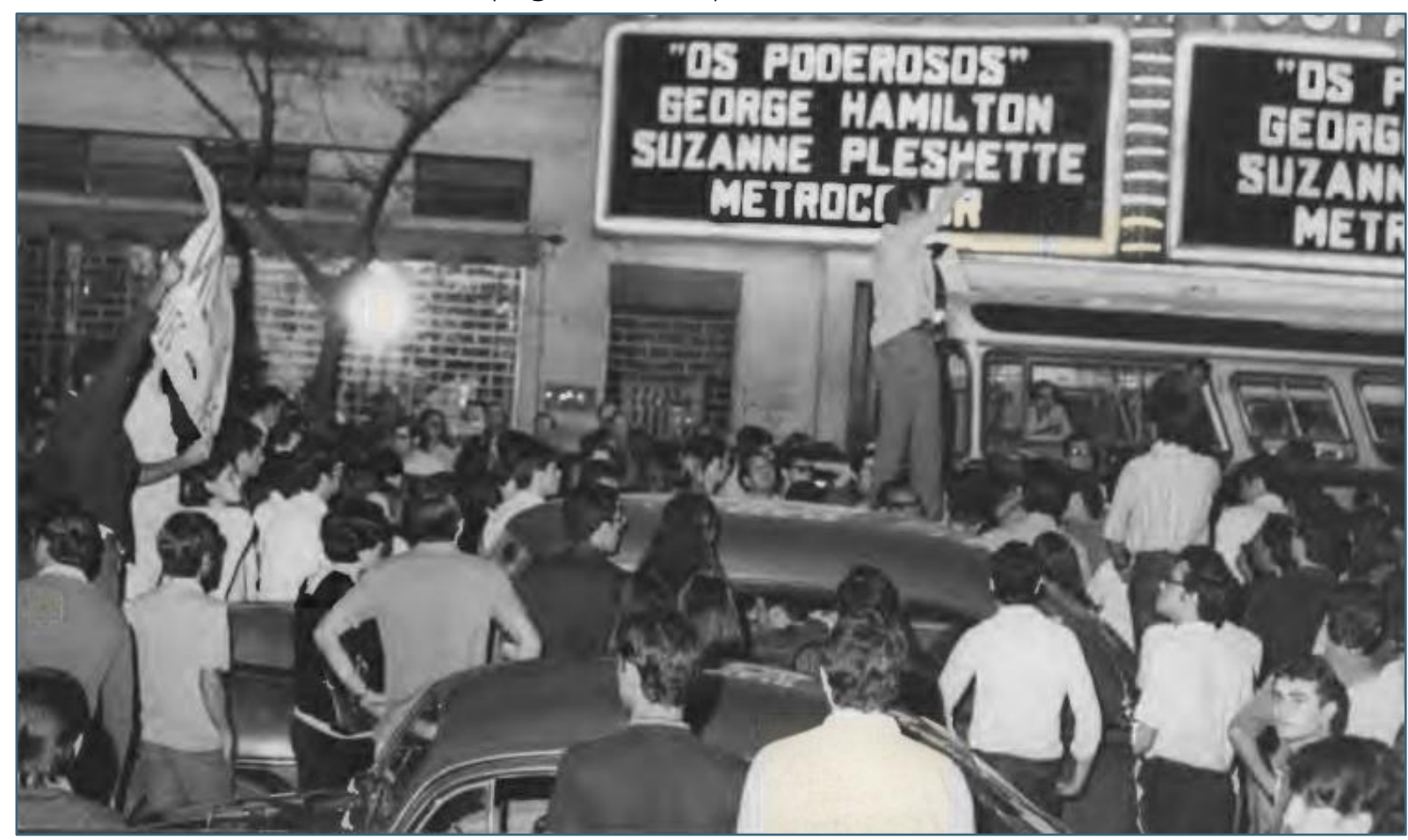

Fonte: Fundo Correio da Manhã - Arquivo Nacional.

Havia cumplicidade entre os fotógrafos do Correio da Manhã e os estudantes. Os jovens perceberam que eles estavam do seu lado, passando a avisá-los onde e quando seria o próximo ato de protesto ou comício-relâmpago (OLIVEIRA, 1998, p. 125). Parecia que os fotógrafos tinham exclusividade para registrar os eventos, o que, inclusive, levantou suspeitas da polícia. Não era casual, portanto, a presença de fotógrafos do CM nos atos conhecidos como comícios-relâmpago.

Retomando algumas reflexões de Boris Kossoy, o fotógrafo interfere na imagem e na configuração do contexto de que faz parte. "Dramatizando ou valorizando esteticamente os cenários” (KOSSOY, 2014, p. 122), afirma o autor, "deformando a aparência de seus retratados [...], omitindo ou introduzindo 
detalhes, elaborando a composição ou incursionando na própria linguagem do meio" (KOSSOY, 2014, p. 122), o fotógrafo manipula seus temas de alguma forma: técnica, estética ou ideologicamente. A fotografia, para Kossoy, é um documento “interpretado no passado antes mesmo da própria tomada do registro" (KOSSOY, 2014, p. 122). É nesse sentido, na defesa da causa dos estudantes, que os fotógrafos, sempre que podiam, recorriam a cartazes de cinema. Os poderosos que clamavam por justiça eram também anjos rebeldes (figura 7).

Figura 7 - Tropa da Polícia Militar recebe instruções do comandante

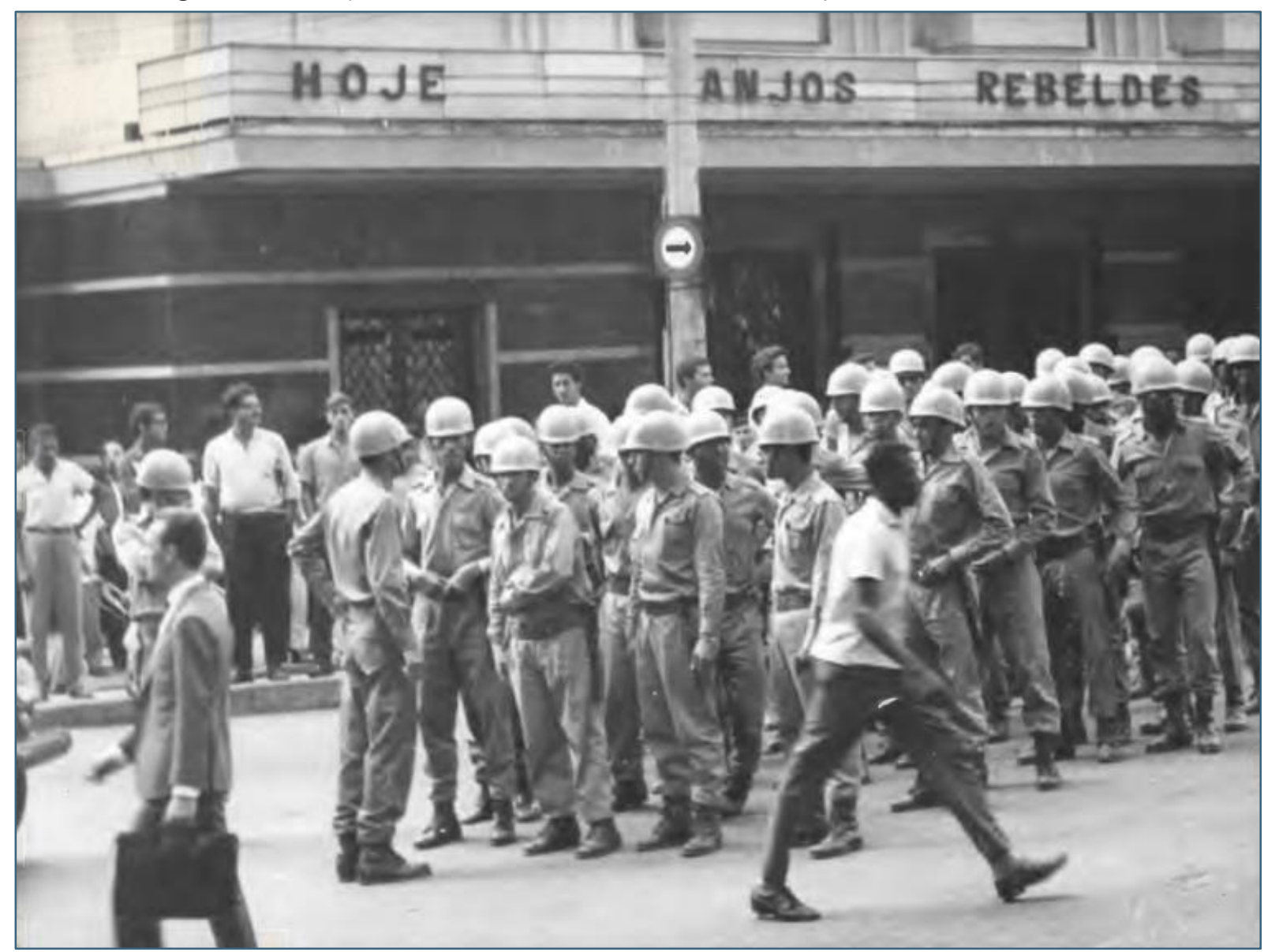

Fonte: Fundo Correio da Manhã - Arquivo Nacional.

Os fotógrafos também recorriam a outros tipos de mensagem escrita, como as placas com nomes de ruas. Em fotografia com esse tipo de recurso, um estudante realiza comício-relâmpago na rua do Ouvidor (figura 8). Por derivação do nome escrito na placa, deduz-se que o jovem deveria, portanto, ser ouvido. Segundo classificações citadas por Charles Monteiro sobre os tipos de fotografias do fotojornalismo, as publicadas no Correio de Manhã sobre os embates nas ruas 
do Rio de Janeiro ao longo de 1968 poderiam ser consideradas spot news (MONTEIRO, 2016, p. 68). A expressão designa imagens não planejadas, criadas no momento em que algo compreendido como "notícia quente" é visto pelo fotógrafo, sendo logo captado por suas lentes 5 .

Figura 8 - Comício relâmpago de estudante no centro do Rio de Janeiro

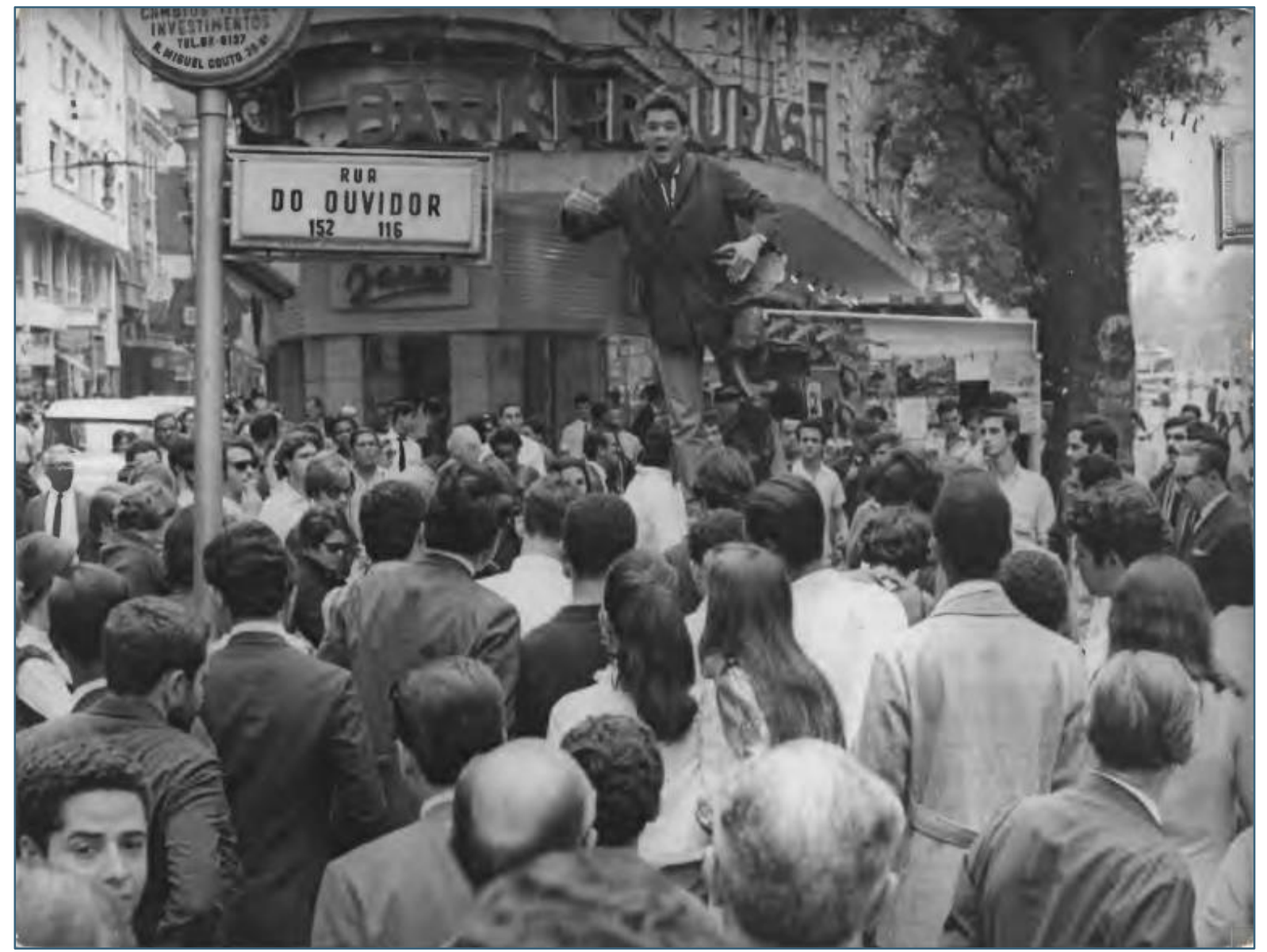

Fonte: Fundo Correio da Manhã - Arquivo Nacional.

Outros tipos de textos foram usados pelos fotógrafos: as pichações de rua. Trata-se de recurso que não dispensava crítica à ditadura. Algumas das fotografias com pichações são divulgadas até os dias atuais.

\footnotetext{
Além do spot news, as outras classificações referem-se a: pseudoacontecimentos, quando o fotografado interfere com poses e gestos; photo-illustration, fotografias produzidas como pinturas; feature-photos, quando o fotógrafo surpreende flagrantes casuais; mug-shot, pequenas fotografias de rostos; picture stories, série de fotografias que contam uma história; e fotoensaio, quando o fotógrafo ou equipe sugere sua própria intepretação sobre o tema (MONTEIRO, 2016, p. 68).
} 
Figura 9 - Na fotografia publicada no dia 2 de abril de 1968, policiais militares, no dia anterior, vigiam o centro da cidade à espera de protestos dos estudantes pela passagem dos quatro anos do golpe civil-militar

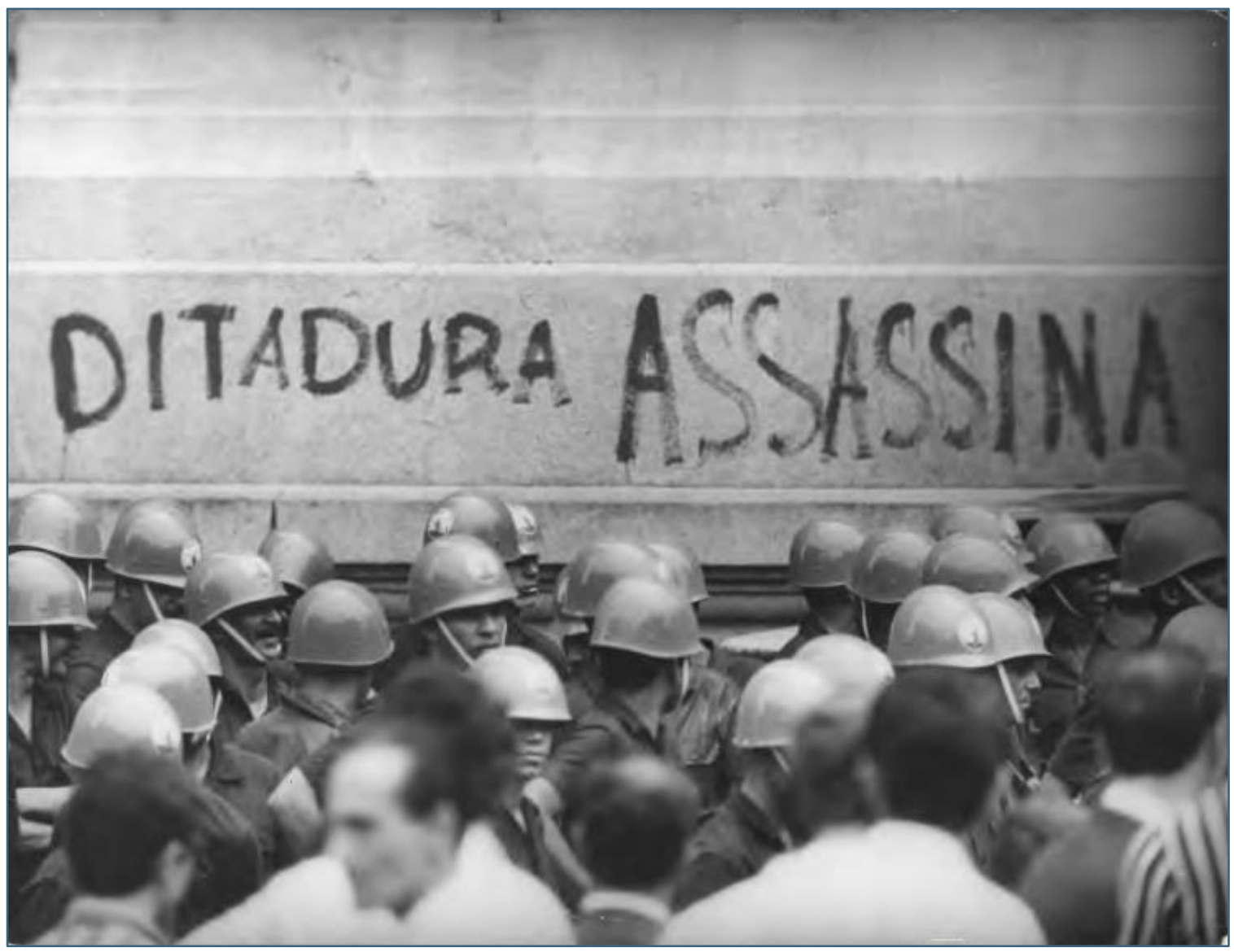

Fonte: Fundo Correio da Manhã - Arquivo Nacional.

Temos acima novo exemplo do olhar fotográfico, uma sensibilidade que incita o fotógrafo a alterar a composição da fotografia (figura 9). O tema principal da foto deveria ser o grupo de soldados da Polícia Militar, enquanto a pichação entraria como elemento secundário. Afinal, o fotógrafo tinha como objetivo noticiar a preparação da PM para enfrentar os estudantes. Mas, se ele fotografasse somente os soldados, teríamos apenas mais uma imagem da PM, uma entre tantas outras. Pode-se dizer que a pichação se tornou o elemento central da fotografia, tomando metade da parte superior do retrato. O fotógrafo tornou o conjunto - soldados e pichação - o próprio elemento central da imagem, tendo por objetivo denunciar que a ditadura era, de fato, assassina. Não sem razão, Gil Vicente Oliveira afirma que o Correio da Manhã exerceu "combate ostensivo ao regime militar instaurado em 1964", citando também a "importância 
fundamental de seu fotojornalismo na construção de um vigoroso discurso oposicionista” (OLIVEIRA, 1998, p. 117).

Por vezes, a composição da fotografia apresenta elementos dispostos, mas sem que se possa identificar, entre eles, o elemento principal. Na foto, quatro crianças leem as pichações dos estudantes (figura 10). O maior deles, com o dedo apontado e o rosto inclinado, está lendo, possivelmente para os menores, ainda em processo de alfabetização. Seriam as crianças o elemento principal da imagem? Ou seriam, talvez, as pichações que aludem à "morte aos gorilas" e à "vingança aos colegas assassinados"? Novamente defendo que a composição é o todo, garotos e pichações, uma vez que os meninos estão lendo as mensagens dos estudantes. O resultado é uma estética visual harmônica. Outro exemplo do que os fotógrafos chamam de olhar fotográfico.

Figura 10 - Palavras-de-ordem estudantis pichadas nos muros e paredes chamavam a atenção, inclusive de crianças.

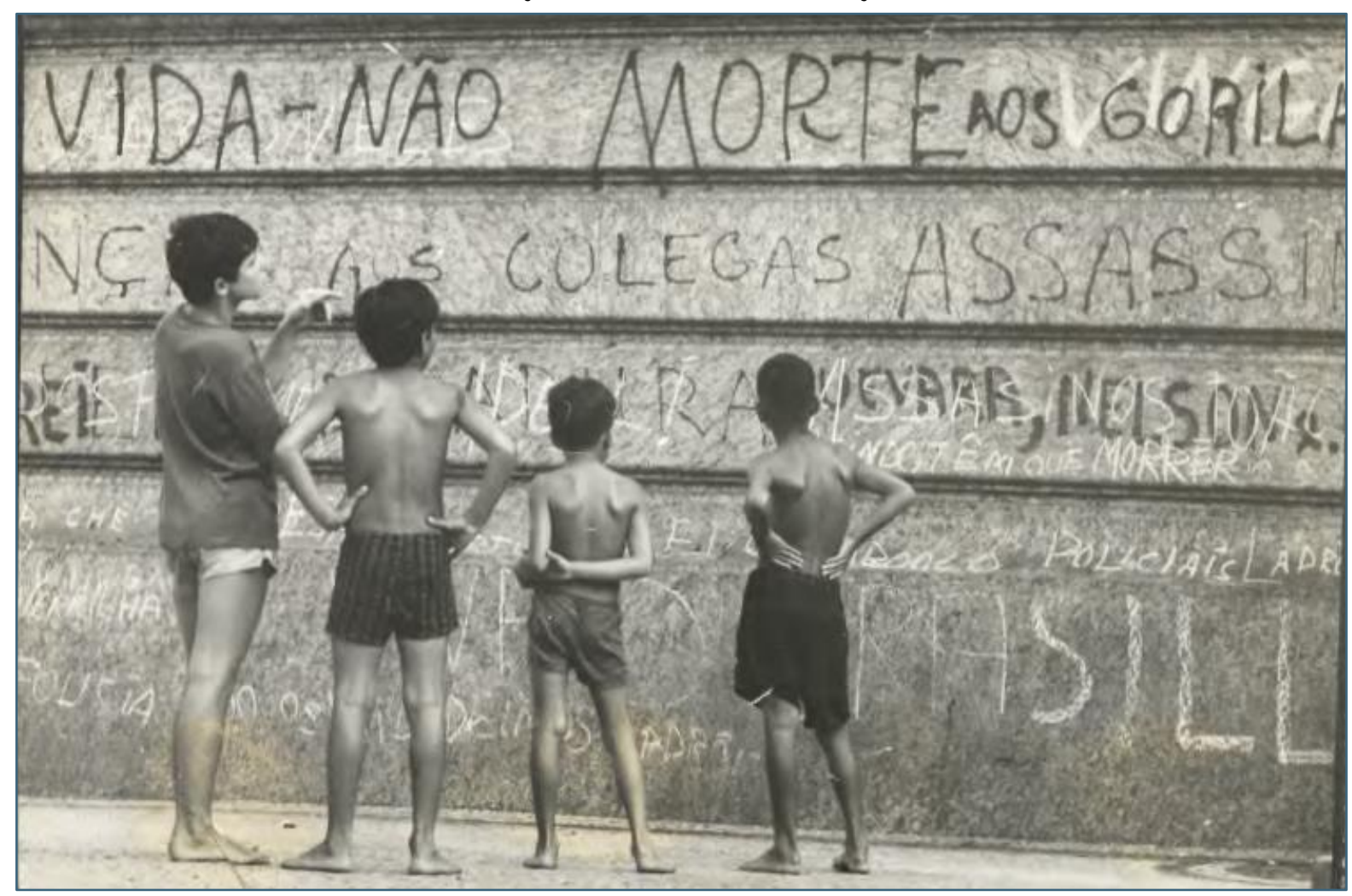

Fonte: Fundo Correio da Manhã - Arquivo Nacional.

Os fotógrafos não perdiam oportunidade para associar soldados do Exército à crítica à ditadura. Na pichação, há o lema de uma corrente do 
movimento estudantil "o povo organizado derruba a ditadura", em contraposição ao de outra corrente: "o povo armado derruba da ditadura" (figura 11). Organizado ou armado, seja como for, interessa ao fotógrafo a mensagem sobre "derrubar a ditadura". As pichações que aludiam à Guerra Fria, ao imperialismo e às lutas de libertação nacional também eram o mote para a composição das fotografias.

Figura 11 - As palavras-de-ordem dos estudantes também eram pichadas em frente de prédios militares

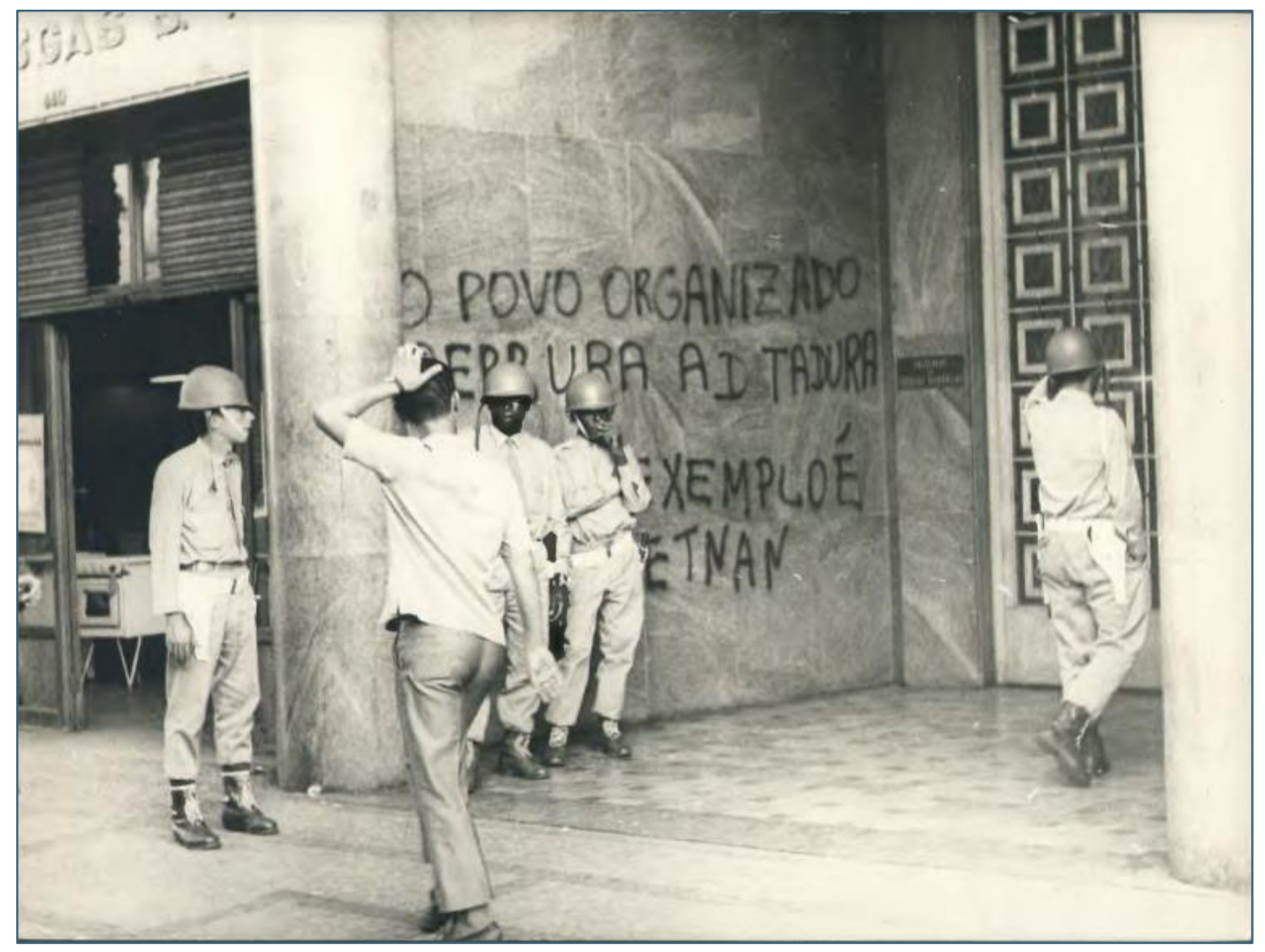

Fonte: Fundo Correio da Manhã - Arquivo Nacional.

\section{O deboche em foco}

Os fotógrafos do Correio da Manhã recorriam a cartazes de cinema nas ruas e a pichações na crítica à ditadura. Também aproveitavam letreiros, comerciais ou informativos no sentido de criticar e debochar da Polícia Militar. 
Figura 12 - Fotógrafo do Correio da Manhã realizou esforço para enquadrar policial e

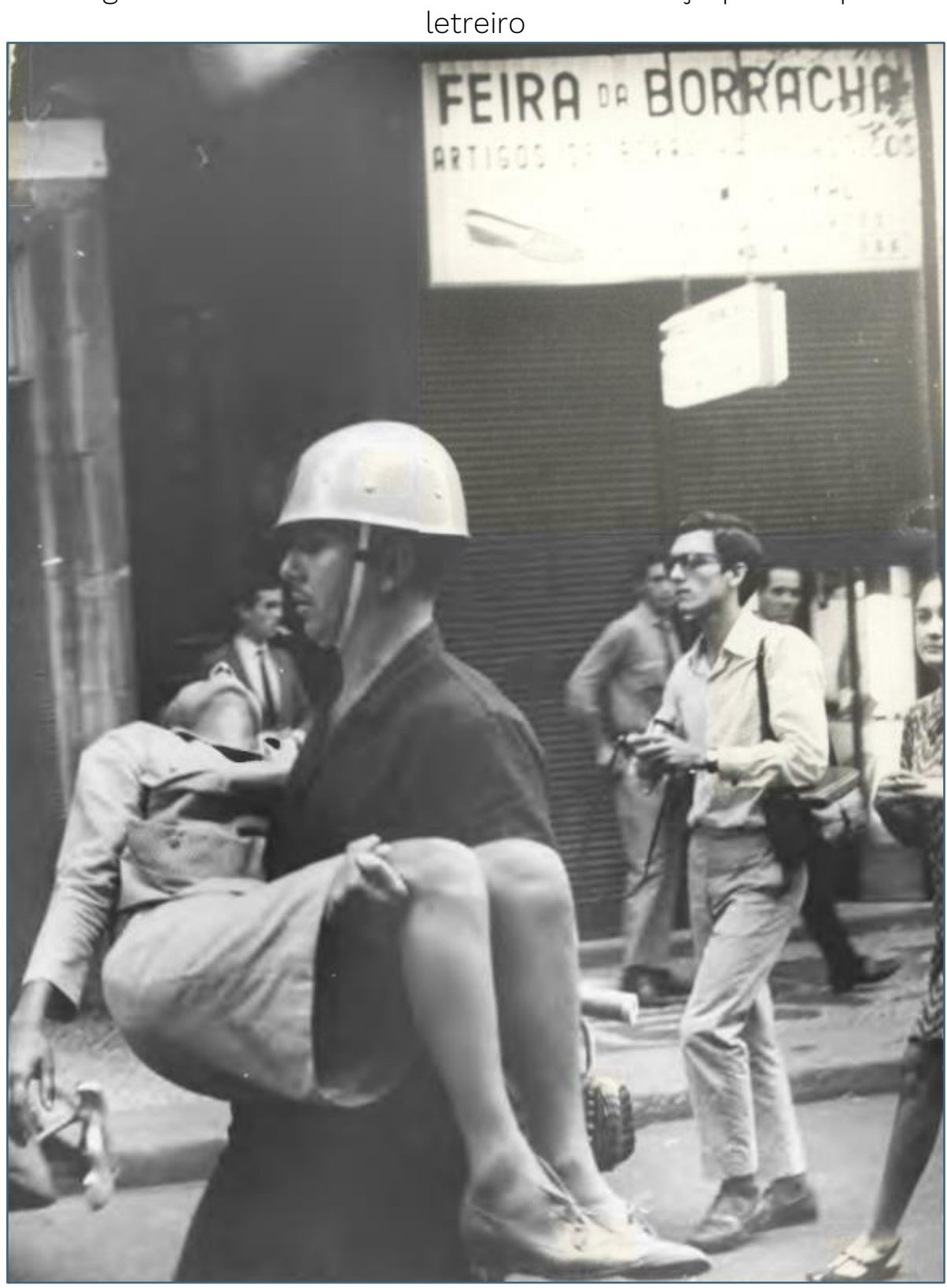

Fonte: Fundo Correio da Manhã - Arquivo Nacional.

A produção da fotografia acima merece ser esmiuçada (figura 12). Na linguagem fotográfica, o motivo do retrato é o soldado da PM que socorre a mulher desmaiada durante os conflitos de rua. A cena é tudo o que gira em torno do motivo: a rua, as pessoas assistindo na calçada, o fotógrafo que caminha atrás do soldado e o cartaz de loja comercial que diz: "feira da borracha". O fotógrafo, sem dúvida, fez um esforço para enquadrar os personagens, numa composição imaginativa da cena. De um lado, ele capta o soldado carregando uma mulher desmaiada; de outro, em fina ironia, aproveita o cartaz sobre a "feira da borracha". 
Borracha, evidentemente, alude ao cassetete do soldado. Vale reiterar o esforço do fotógrafo no enquadramento harmonioso: o cartaz no alto, à direita, e o soldado carregando a mulher na parte de baixo, à esquerda. Eis o resultado da "feira da borracha".

Nas ruas, painéis publicitários, os outdoors, também eram aproveitados para criticar o governo militar, como o da empresa de aparelhos para surdez (figura 13). Quem é surda é a ditadura. Não ouve. Portanto, não há diálogo, não há conversa. "Nas fotografias publicadas, havia ironia e sarcasmo, nem sempre sutis, nas quais se destilava uma crítica mordaz ao governo militar", afirma Gil Vicente Oliveira (1998, p. 120).

Figura 13 - Fotógrafo aproveitou a oportunidade para associar policiais militares à mensagem do outdoor

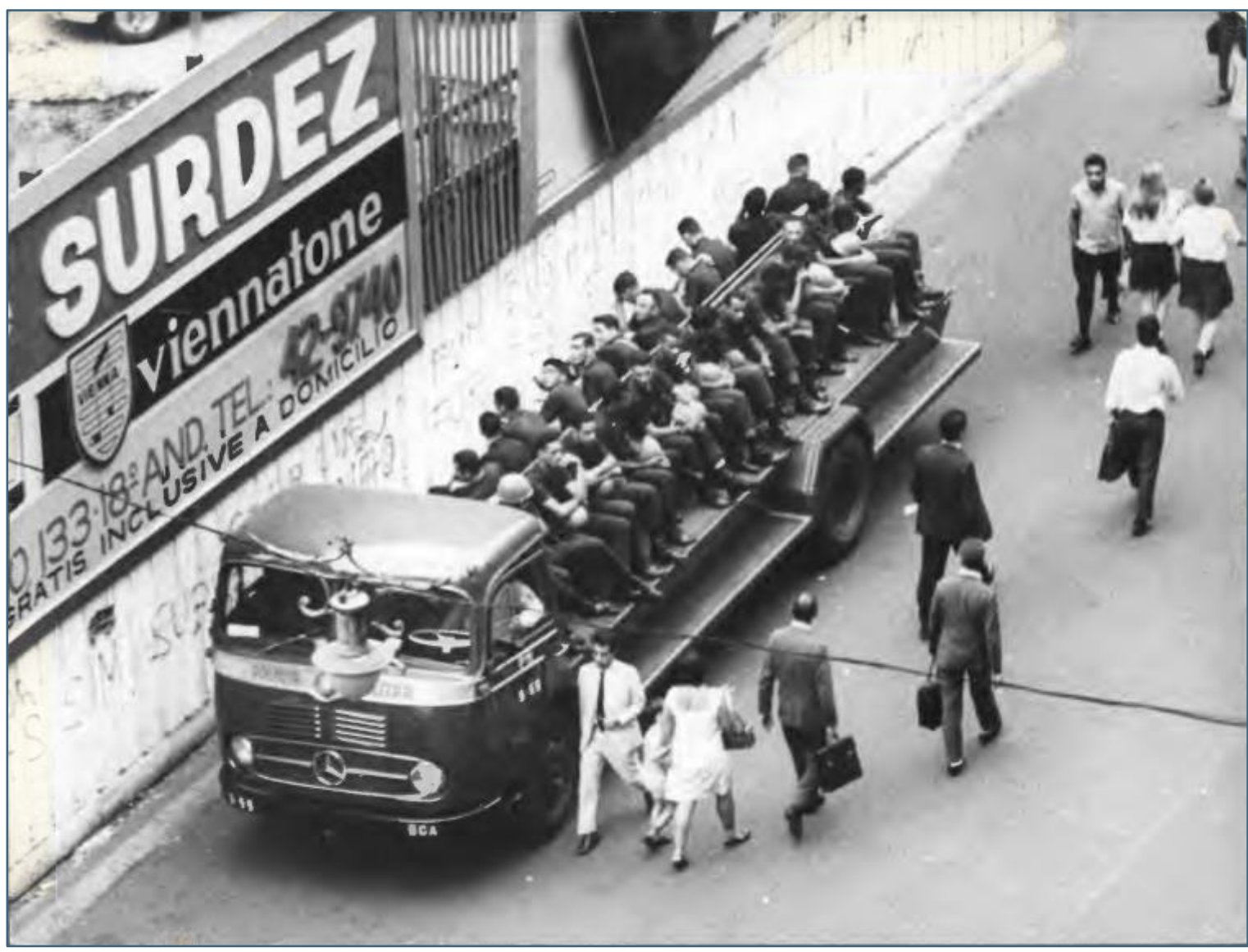

Fonte: Fundo Correio da Manhã - Arquivo Nacional.

Cartazes de rua davam aos fotógrafos a oportunidade para exaltar a luta dos estudantes. O olhar fotográfico permitiu associar um grupo de estudantes que, na "sexta-feira sangrenta", avançava contra a PM, ao outdoor que fazia 
chamada publicitária do cigarro Vitória: "o único que não brinca em serviço", sobretudo quando armados com pedras e paus (figura 14). As fotografias, portanto, não surgem nas páginas do jornal como meras ilustrações do texto. Como afirma Boris Kossoy, a imagem fotográfica é um documento que "informa sobre o mundo e a vida, porém em sua expressão e estética próprias." (KOSSOY, 2014, p. 169).

Figura 14 - Estudantes foram fotografados durante os conflitos da "sexta-feira sangrenta”. Como a imagem anterior, o fotógrafo enquadrou os estudantes associando-os à mensagem do outdoor

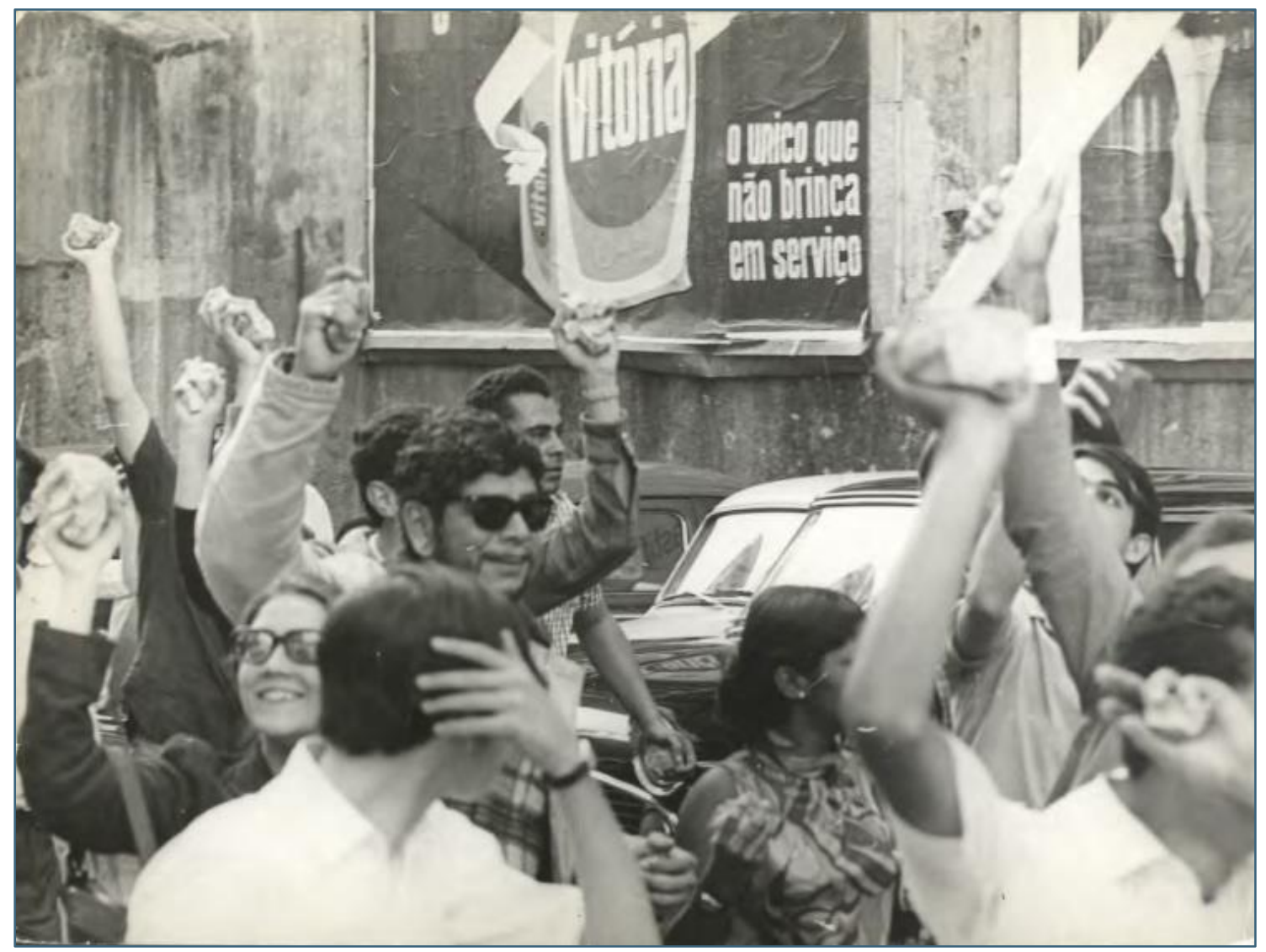

Fonte: Fundo Correio da Manhã - Arquivo Nacional.

Ao criticar a Polícia Militar, por vezes os fotógrafos reproduziam preconceitos próprios de seu tempo. É o caso de chamar um homem de mulher. Para a época, era xingamento grave questionar a masculinidade de um homem, principalmente definindo-o como mulher. O fotógrafo, nesse sentido, foi objetivo na ofensa ao registrar um grupo de soldados sob a placa que apontava para o Corpo de Polícia Feminina do Estado da Guanabara (figura 15). Mais que chacota, era um ultraje. 
Figura 15 - Policiais foram fotografados sob placa indicativa da sede da Polícia Feminina

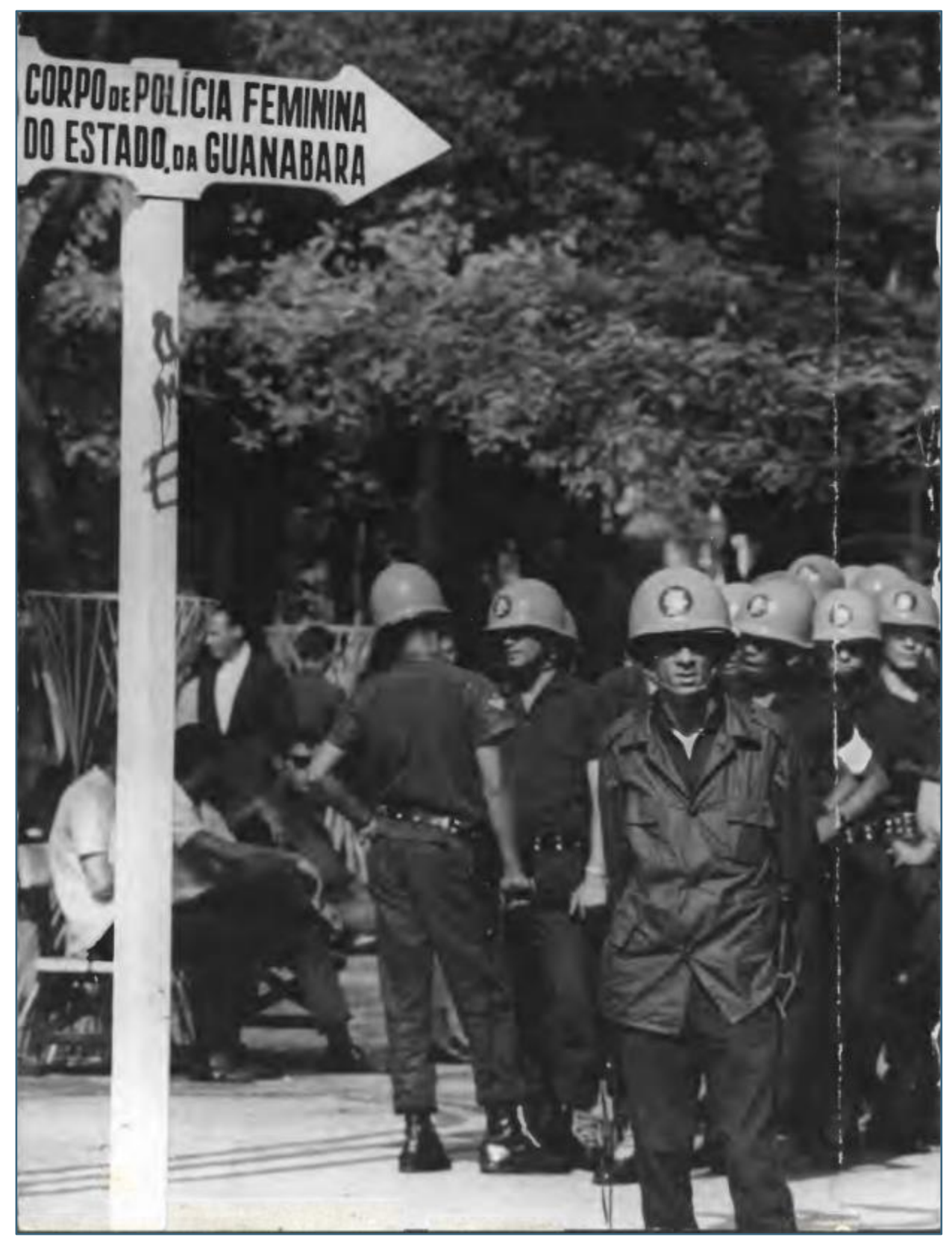

Fonte: Fundo Correio da Manhã - Arquivo Nacional.

O mesmo preconceito foi utilizado em outra fotografia (figura 16). Sobre as cabeças dos militares, o cartaz da artista Rogéria na peça "Oh! Que delícia de bonecas". Para os padrões de masculinidade vigentes na época, mais que uma ofensa, tratava-se de uma chacota ${ }^{6}$.

\footnotetext{
- Segundo pesquisa de Rodrigo Patto Sá Motta, o Correio da Manhã também contava com grupo de chargistas que, com ironia, criticava o governo militar. Entre eles estavam Fortuna, Jota, Claudius, Mem de Sá, Rajão, Senna e Redi. A partir de 1967 e 1968, as críticas à ditadura no CM aumentaram, da mesma maneira que ocorria em Última Hora (MOTTA, 2013, p. 76).
} 
Figura 16 - Policiais foram fotografados tendo ao fundo cartaz artístico

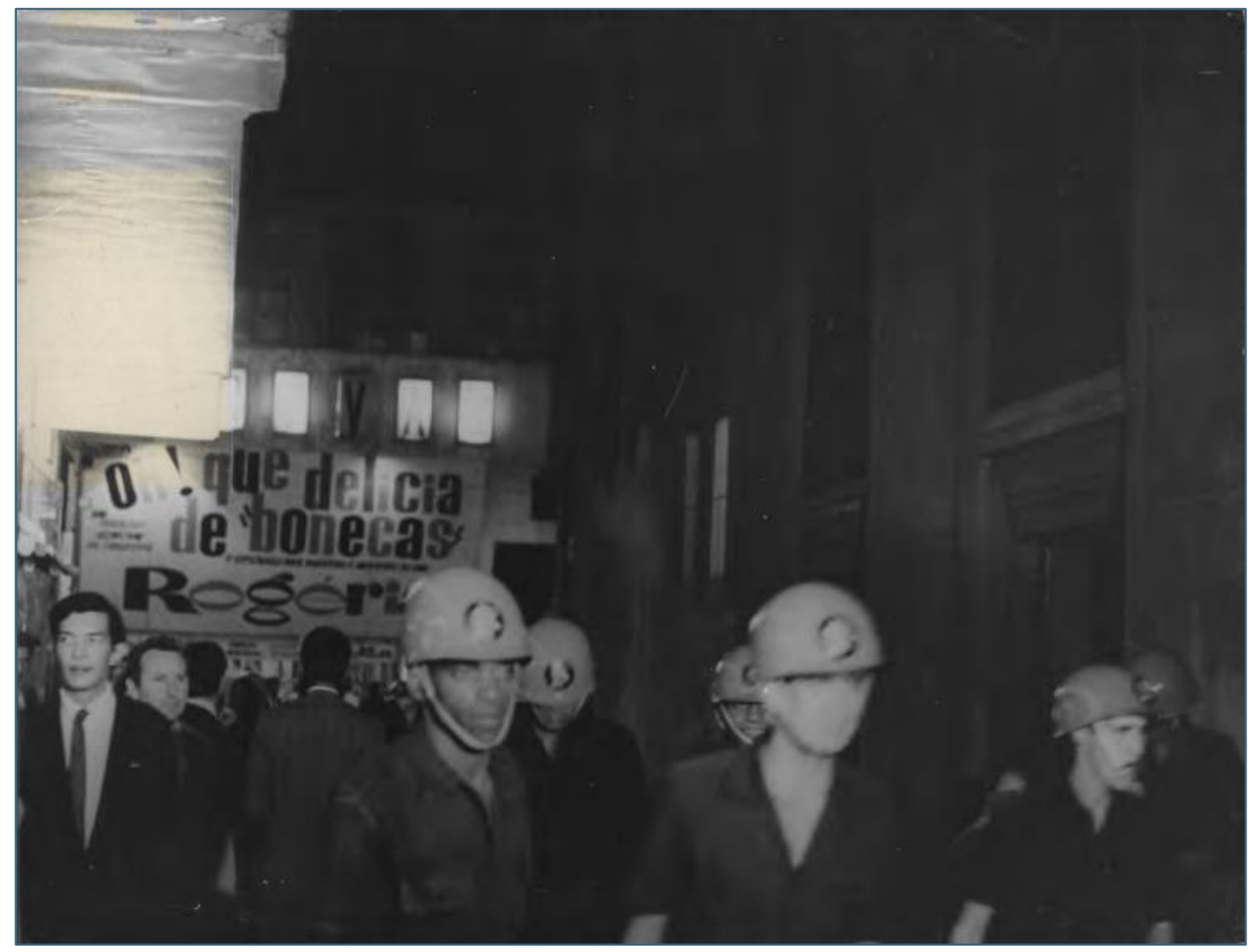

Fonte: Fundo Correio da Manhã - Arquivo Nacional.

\section{Focando um novo mundo}

O fotojornalismo requer imaginação, inventividade e proveito da oportunidade - elementos que contribuem para o olhar fotográfico. Por isso, as imagens captadas pelo diafragma da câmara não são casuais. Quero terminar o artigo com duas fotografias. Ambas foram produzidas em momento de rara inspiração e oportunidade, deixando em aberto nossa capacidade interpretativa.

A primeira retrata um soldado e um estudante de colégio estadual, um ao lado do outro, em exemplo do que chamo, aqui, repetidamente, de olhar fotográfico (figura 17). O motivo da fotografia conjuga o caderno do estudante ao revólver do soldado, razão pela qual o enquadramento se circunscreve à cintura e aos quadris de ambos. A composição, por sua vez, não articula o elemento do primeiro plano ao do secundário. Arma e caderno formam a cena, o motivo, o enquadramento e a composição da fotografia, permitindo múltiplas leituras. 
Figura 17 - Fotografia de estudante secundarista preso por policial militar

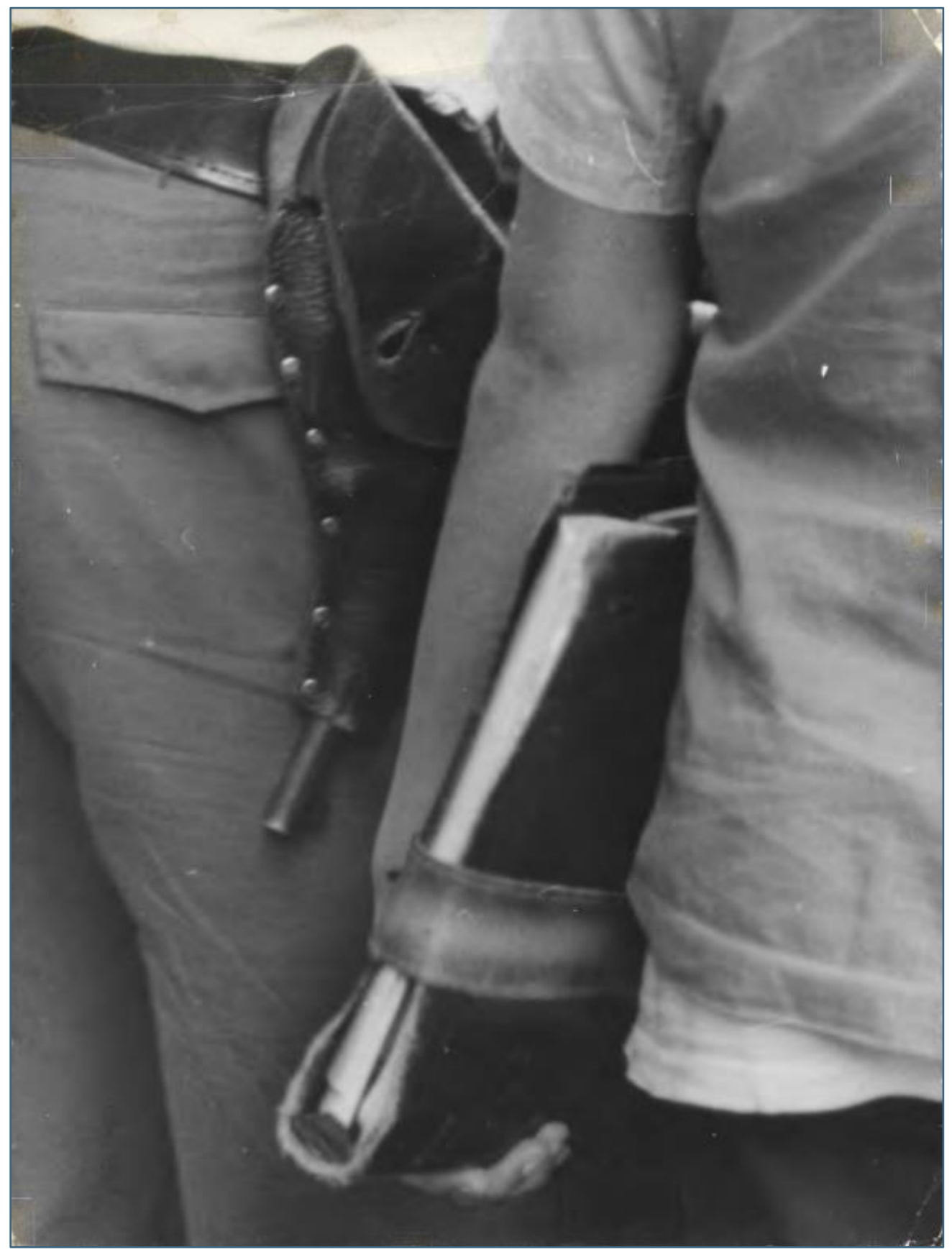

Fonte: Fundo Correio da Manhã - Arquivo Nacional.

A segunda fotografia é de raro oportunismo do fotógrafo (figura 18). Dezenas de soldados da Polícia Militar são transportados em caminhões da empresa de limpeza urbana. Reitera-se: os homens são levados por caminhões de lixo. Na foto, os soldados são a metáfora da ditadura militar. Ao lado, uma publicidade comercial anuncia "Novo Mundo". Possivelmente foi essa a mensagem que o fotógrafo quis nos passar: quando a ditadura for varrida do cenário político, teremos, finalmente, o novo mundo tão sonhado. 
Figura 18 - Na fotografia, policiais são transportados por caminhões da empresa de limpeza urbana

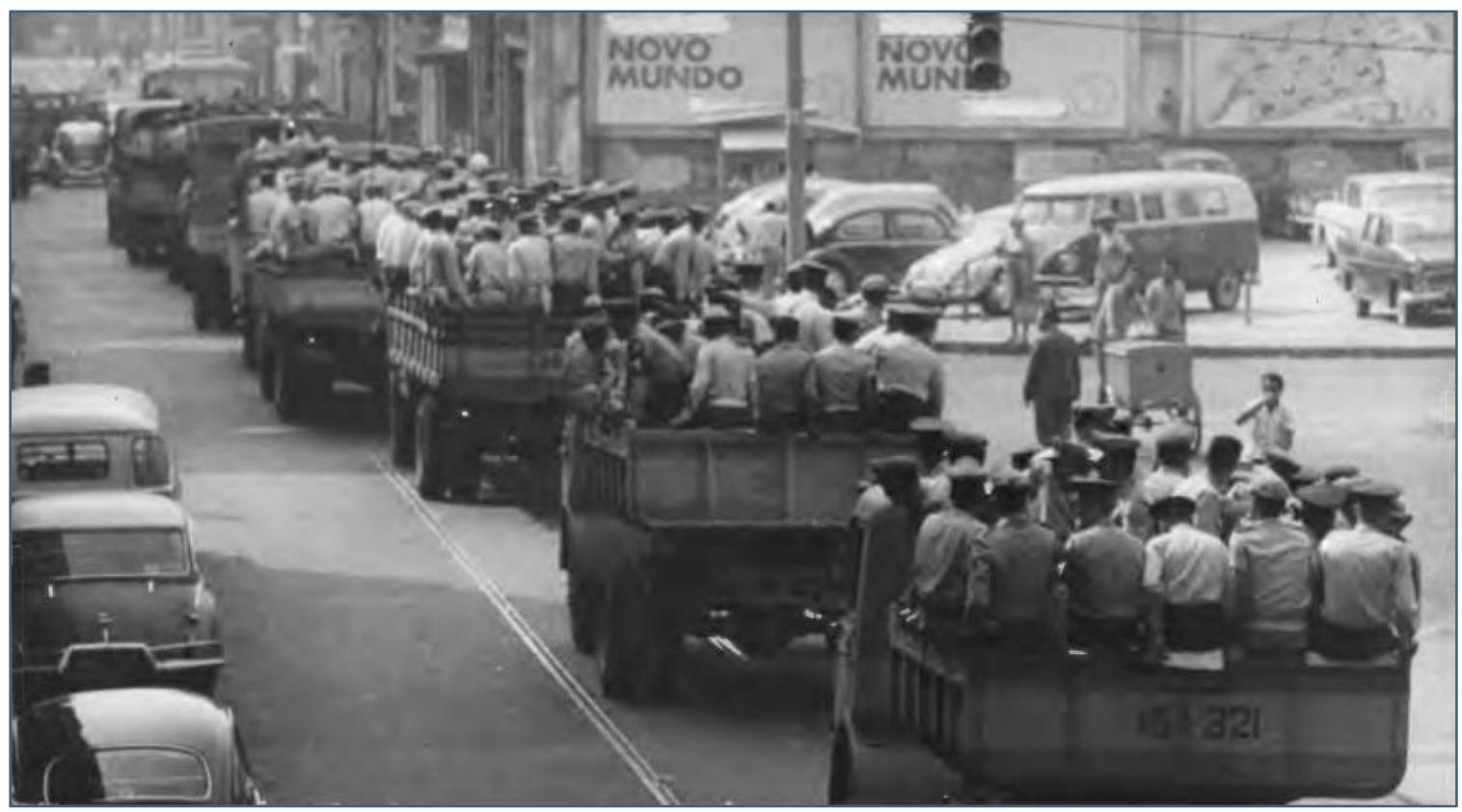

Fonte: Fundo Correio da Manhã - Arquivo Nacional.

Seja como for, após a Passeata dos Cem Mil, auge do movimento estudantil, em 26 de junho de 1968, houve início do refluxo das escaramuças de rua. O recuo foi acentuado com as prisões ocorridas durante o XXX Congresso da UNE, na localidade de Ibiúna, estado de São Paulo, em 12 de outubro de 1968. Centenas de estudantes foram presos, algo que abalou o movimento estudantil. O refluxo dos embates também foi causado pelo aumento da repressão policial: "protestos contra assassinatos resultavam em mais assassinatos. As mortes em manifestações públicas tornaram-se anônimas, banais. [...] A polícia já não hesitava em dissolver à bala manifestações pacíficas, invadir igrejas e hospitais" (REIS; MORAES, 2008, p. 26).

Com o Al-5, decretado em 13 de dezembro daquele ano, e a imposição da censura prévia, o movimento estudantil foi derrotado e a imprensa de oposição foi obrigada a calar-se. O Correio da Manhã e o Última Hora foram os dois jornais da chamada grande imprensa que, desde o golpe de Estado de 1964, manifestaram oposição frontal à ditadura militar. "Os grandes jornais", afirma com razão Rodrigo Patto Sá Motta, "na maioria, se acomodaram à situação política, comportamento, aliás, comum na nossa cultura política” (MOTTA, 2013, p. 85). 
Em 1969, o Correio da Manhã viveu grave crise econômica com a ausência dos anúncios de empresas. Jornalistas e fotógrafos foram demitidos e o número de páginas, reduzido. Não havia mais em suas páginas fotografias que denunciavam as violências do regime. Em março, o jornal pediu concordata, e Niomar, processada pela Lei de Segurança Nacional, escapou da prisão por um habeas corpus, mas teve seus direitos políticos cassados. Erno Schneider, por sua vez, foi convidado para trabalhar em O Globo. Schneider aceitou, desde que pudesse levar consigo cinco fotógrafos. Roberto Marinho concordou. Niomar ainda tentou dar sobrevida ao Correio de Manhã, mas, em 1975, o jornal entrou em processo de falência e encerrou suas atividades (OLIVEIRA, 1998, p. 131-132). Os estudantes retornariam às ruas dois anos depois, em 1977.

\section{Referências}

ABREU, Alzira Alves et al. A imprensa em transição: jornalismo brasileiro nos anos 50. Rio de Janeiro: FGV, 1996.

DIRCEU, José; PALMEIRA, Vladimir. Abaixo a ditadura. O movimento de 68 contado por seus líderes. Rio de Janeiro: Espaço e Tempo/Garamond, 1998.

HUMBERTO, Luis. Fotografia, a poética banal. Brasília: Editora da UnB; São Paulo: Imprensa Oficial do Estado, 2000.

KOSSOY, Boris. Fotografia e história. 5. ed. rev. São Paulo: Ateliê Editorial, 2014.

LEAL, Carlos Eduardo. Correio da Manhã: verbete. Rio de Janeiro: FGV CPDOC, [c2009]. Disponível em: http://www.fgv.br/cpdoc/acervo/dicionarios/verbetetematico/correio-da-manha. Acesso em: 26 dez. 2016.

MENESES, Ulpiano T. Bezerra. A fotografia como documento - Robert Capa e o miliciano abatido na Espanha: sugestões para um estudo histórico. Tempo, Rio de Janeiro: v. 7, n. 14, jan-jun 2003.

MAUAD, Ana Maria. Através da imagem: fotografia e história interfaces. Tempo. Rio de Janeiro: vol. 1, n. 2, 1996. 
MONTEIRO, Charles. História e fotojornalismo: reflexões sobre o conceito e a pesquisa na área. Revista Tempo e Argumento. Florianópolis: v. 8, n. 17, jan./abr. 2016.

MOTTA, Rodrigo Patto Sá. Em guarda contra o "perigo vermelho". O

anticomunismo no Brasil (1917-1964). São Paulo: Perspectiva/Fapesp, 2002.

MOTTA, Rodrigo Patto Sá. A ditadura nas representações verbais e visuais da grande imprensa: 1964-1969. Topoi. Revista de História. Rio de Janeiro: vol. 14, n. 26, jan-jun 2013.

OLIVEIRA, Gil Vicente Vaz. Fotojornalismo subversivo. 1968 revisto pelas lentes do Correio da Manhã’. Acervo. Rio de Janeiro: v. 11, n. 1-2, jan./dez. 1998.

PITTS, Bryan. "O sangue da mocidade está correndo": a classe política e seus filhos enfrentam os militares em 1968. Revista Brasileira de História. São Paulo: v. 34, n. 67, 2014.

REIS, Daniel Aarão; MORAES, Pedro de. 1968. A paixão de uma utopia. 3a edição. Rio de Janeiro: FGV, 2008.

TEIXEIRA, Evandro. A fotografia a serviço da luta contra a ditadura militar no Brasil. [Entrevista cedida à Paulo César Boni]. Discursos fotográficos. Londrina, v. 8, n. 12, jan./jun. 2012.

VENTURA, Zuenir. 1968. O ano que não terminou. A aventura de uma geração. Rio de Janeiro: Nova Fronteira, 1988.

\section{Referências das fotografias}

Figura 1: Arquivo Nacional, BR RJANRIO PH O FOT 00229 (217)

Figura 2: Arquivo Nacional, BR RJANRIO PH O FOT O0229 (321)

Figura 3: Arquivo Nacional, BR RJANRIO PH O FOT 00229 (410)

Figura 4: Arquivo Nacional, BR RJANRIO PH O FOT 00229 (168)

Figura 5: Arquivo Nacional, BR RJANRIO PH O FOT 00229 (441)

Figura 6: Arquivo Nacional, BR RJANRIO PH O FOT 00229 (3)

Figura 7: Arquivo Nacional, BR RJANRIO PH O FOT 00229 (456) 
Figura 8: Arquivo Nacional, BR RJANRIO PH O FOT 00229 (669)

Figura 9: Arquivo Nacional, BR RJANRIO PH O FOT 00229 (461)

Figura 10: Arquivo Nacional, BR RJANRIO PH O FOT 00229 (411)

Figura 11: Arquivo Nacional, BR RJANRIO PH O FOT 00229 (470)

Figura 12: Arquivo Nacional, BR RJANRIO PH O FOT 00229 (367)

Figura 13: Arquivo Nacional, BR RJANRIO PH O FOT 00229 (234)

Figura 14: Arquivo Nacional, BR RJANRIO PH O FOT 00229 (36)

Figura 15: Arquivo Nacional, BR RJANRIO PH O FOT 00229 (485)

Figura 16: Arquivo Nacional, BR RJANRIO PH O FOT 00229 (120)

Figura 17: Arquivo Nacional, BR RJANRIO PH O FOT 00229 (344)

Figura 18: Arquivo Nacional, BR RJANRIO PH O FOT 00229 (524) 